\title{
SARS-CoV-2 / COVID-19 PANDEMIC - AN UPDATE
}

Ramya Shanmugam ${ }^{1}$, Sangeetha Thangavelu ${ }^{1}$, Zareena Fathah ${ }^{2}$, Mohd. Iqbal Yatoo ${ }^{3}$, Ruchi Tiwari ${ }^{4}$, Megha Katare Pandey ${ }^{5}$, Jaideep Dhama ${ }^{6}$, Ram Chandra ${ }^{7}$, Yashpal Singh Malik ${ }^{8}$, Kuldeep Dhama ${ }^{9 *}$ (D), Ranjit $\mathrm{Sah}^{10}$, Wanpen Chaicumpa ${ }^{11}$, Velayuthaprabhu Shanmugam ${ }^{12}$, Vijaya Anand Arumugam ${ }^{1 *}$

\footnotetext{
${ }^{1}$ Medical Genetics and Epigenetics Laboratory, Department of Human Genetics and Molecular Biology, Bharathiar University, Coimbatore-641046, Tamil Nadu, India ${ }^{2}$ King's College London, London, United Kingdom

${ }^{3}$ IndiaDivision of Veterinary Clinical Complex, Faculty of Veterinary Sciences and Animal Husbandry, Shuhama, Alusteng Srinagar, Sher-E-Kashmir University of Agricultural Sciences and Technology of Kashmir, Shalimar, Srinagar-190006, Jammu and Kashmir, India

${ }^{4}$ Department of Veterinary Microbiology and Immunology, College of Veterinary Sciences, Uttar Pradesh Pandit Deen Dayal Upadhyaya Pashu Chikitsa Vigyan Vishwavidyalaya Evam Go Anusandhan Sansthan (DUVASU), Mathura, India-281001,

${ }^{5}$ Department of Veterinary Pathology, College of Veterinary Science, Durg- 491001, Chhattisgarh, India

${ }^{6}$ Department of Ophthalmology, Tara Hospital, Uttam Nagar, New Delhi -11059, India

${ }^{7}$ Department of Microbiology, School of Environmental Sciences, Babasaheb Bhimrao Ambedkar University, (A Central University) Vidya Vihar, Raebareli Road, Lucknow-226025, UP., India

${ }^{8}$ Division of Biological Standardization, ICAR-Indian Veterinary Research Institute, Izatnagar, Bareilly- 243 122, Uttar Pradesh, India

${ }^{9}$ Division of Pathology, ICAR-Indian Veterinary Research Institute, Izatnagar, Bareilly-243 122, Uttar Pradesh, India

${ }^{10}$ Tribhuvan University Teaching Hospital, Institute of Medicine, Kathmandu, Nepal

${ }^{11}$ Center of Research Excellence on Therapeutic Proteins and Antibody Engineering, Department of Parasitology, Faculty of Medicine Siriraj Hospital, Mahidol University, Bangkok 10700, Thailand

${ }^{12}$ Department of Biotechnology, Bharathiar University, Coimbatore-641046, Tamil Nadu, India
}

Received - September 25, 2020; Revision - November 10, 2020; Accepted - November 15, 2020

Available Online November 20, 2020

DOI: http://dx.doi.org/10.18006/2020.8(Spl-1-SARS-CoV-2).S219.S245

\section{KEYWORDS \\ SARS-CoV-2 \\ COVID-19 \\ Pandemic \\ Pathology \\ Diagnosis \\ Treatment}

\begin{abstract}
The coronavirus disease - 2019 (COVID-19) pandemic, caused by severe acute respiratory syndrome coronavirus virus - 2 (SARS-CoV-2), set it foots in China during December 2019 as a high-alert public health emergency. This malady had thereafter spread rapidly across the globe in more than 215 countries, affecting more than 50 million people and causing the death of nearly 1.3 million as of $9^{\text {th }}$ November, 2020 and resulted in a massive panic, fear, and economic crashes in most of the world. A better understanding of the disease, the virus, structural biology, clinical manifestations, risk factors, transmission, diagnosis, treatment, and management can be extrapolated from the literature review of the research up to date. In addition, deliberations on animal linkages, spillover and zoonotic implications for exploring the actual origin of the disease and all possible animal-human interfaces, intermediate host; diagnosis for devising specific and sensitive tests of ease,
\end{abstract}

* Corresponding author

E-mail: kdhama@rediffmail.com (Dr. Kuldeep Dhama); avahgmb@buc.educ.in (Dr. Vijaya Anand Arumugam)

Peer review under responsibility of Journal of Experimental Biology and Agricultural Sciences.

Production and Hosting by Horizon Publisher India [HPI] (http://www.horizonpublisherindia.in/).

All rights reserved.
All the articles published by Journal of Experimental Biology and Agricultural Sciences are licensed under a Creative Commons Attribution-NonCommercial 4.0 International License Based on a work at www.jebas.org.

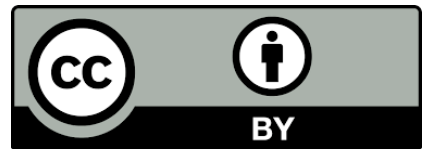


accessibility and affordability; advances in the development of safe and effective vaccines and therapeutics for prevention and treatment; management of COVID-19 practicable in all countries; application of traditional or regularly used modalities including plant-based products and medicinal herbs against SARS-COV-2; nutritious dietary foods against this disease; and socio-economic impacts of COVID-19 can provide valuable information on these various aspects. Most of the research currently focuses on disease, development of a vaccine or therapeutic modalities. But the future mortality rate and virulence of virus not only depends on the evolution of the virus, but also on how we develop preventive measures and effective treatment as well as in advance preparedness. The present review highlights salient aspects of SARS-CoV-2 / COVID-19, pathology, risk factors, transmission, diagnosis, potential treatment, and alternative / supportive therapeutic options.

\section{Introduction}

A group of eight virologists, including J. D. Almeida, D. M. Berry, C. H. Cunningham, D. Hamre, M. S. Hofstad, L. Mallucci, K. McIntosh, and D. A. J. Tyrrell, relayed their findings on Coronavirus to the Journal Nature in 1968 (Almeida et al., 1968), and as of now, Coronavirus disease - 2019 (COVID-19) is currently causing pandemic, the deadliest after the pandemic Spanish flu in 1918 (Liu et al., 2020a). COVID-19, caused by severe acute respiratory syndrome coronavirus -2 (SARS-CoV-2) that emerged during December 2019 from Wuhan, China, has now spread rapidly to more than 215 countries accounting to nearly 1.3 million deaths out of more than 50 million confirmed cases as of $9^{\text {th }}$ November 2020, and resulted in the serious health concerns, global panic, social, as well as economic consequences with the effects still being increased continuously (Dhama et al., 2020a; Ciotti, 2020; https://www.worldometers.info/coronavirus/). The novel coronavirus emanated from a local fish and wild animal market in Wuhan, China, which was considered as the diversified form of severe acute respiratory syndrome coronavirus (SARS-CoV) (2002-2003) and Middle East respiratory syndrome coronavirus (MERS-CoV) which occurred during the year 2012.

SARS-CoV-2, which initially evolved as an outbreak of pneumonia, affects humans with severe and multiple clinical manifestations and mortality while creating locked down situations in several countries, which are being lifted out for economic survivability. The number of cases and fatalities are continuously increasing daily; it creates the requirement to enhance our understanding of the transmission and epidemiology of the virus. However, within a few months of the outbreak, much information on the virus genome, evolution, transcriptomic mapping and human-virus protein interactions were available. This information is required for identifying the therapeutic targets and development of vaccines, moreover to preventive and patient care policies (Uddin et al., 2020). Effective vaccines and/or drugs are not available yet, for which purpose researchers are trying hard for developing potent vaccines, drugs, and therapies, few of which reached clinical trials, however, few more are still required to reach to the market. More recently, Russia and China have claimed to develop / patent SARS-CoV-2 vaccine. The rapid detection of SARS-CoV-2, strict mitigation, and control strategies are helping in avoiding the virus infection, however, due to high transmission rates, the virus is affecting more and more people continuously. More insights into SARS-CoV-2 epidemiology, molecular biology, pathobiology, immunology, associated risk factors, and revealing zoonotic concerns will help to better understand this virus and the disease it is causing (COVID-19) and facilitate to develop potent vaccines, drugs, and therapies for safeguarding the health of the mass population from this devastating pandemic. The present review highlights salient features of SARS-CoV-2 and COVID-19, associated risk factors, virus/disease transmission, advances in diagnosis, and potential therapeutic options.

\section{Methodology}

The current literature review is mainly focussed on the ongoing pandemic, COVID-19 and hence, few of the important research manuscripts and interesting review articles, which have been published in the standard journals and the databases such as PubMed, PubMed Central, ScienceDirect, Nature, Springer, were searched by using the keywords, COVID-19, SARS-CoV, pandemic, pathology, diagnosis, treatment, nutrition, and related terms. Nearly 300 published articles on various aspects of SARS-CoV-2 / COVID-19 were analysed, and the current data have been scrutinized from important information out of these studies.

\section{SARS-CoV-2}

COVID-19 is a novel form of the pathogenic disease caused by a member of the Cornaviridae family, which has been identified in Wuhan, China, at the end of 2019. The name of the causative virus was subsequently recommended as Severe Acute Respiratory Syndrome Coronavirus - 2 by the International Committee on Taxonomy of Viruses (ICTV), since the virus was related to SARSCoV that caused SARS outbreak in 2003 (Yuen et al., 2020; ICTV, 2020). On 11 February 2020, the World Health Organization (WHO), announced the name of the disease caused by the new virus as COVID-19.

SARS-CoV-2 has been found to have more than $88 \%$ of the close sequence identity with that of two bat-derived SARS-like coronaviruses (bat-SL-CoVZC45 and bat-SL-CoVZXC21); similarly, higher identity was reported with previously published 
Bat_SARS-like CoVs by other researchers but was less related to SARS-CoV (about 79\%) and MERS-CoV (about 50\%) (Chan et al., 2020; Lu et al., 2020a; Malik et al., 2020a; Zhu et al., 2020). Recently, Zhou et al. (2020a) demonstrated a 96.2\% sequence similarity of the bat coronavirus with the human virus.

\section{Classification of SARS-CoV-2}

Coronaviruses has been classified by the ICTV, as shown in Table 1. The SARS-CoV-2 is a member of the family Coronaviridae, subfamily Orthocoronavirinae that has been classified into four genera named as Alpha $(\alpha)$-coronavirus, Beta $(\beta)$-coronavirus, Gamma $(\gamma)$ coronavirus and Delta $(\delta)$-coronavirus. The Alphacoronavirus and Betacoronavirus infect humans and other mammals, whereas the Gammacoronavirus affects the avian species, while the Deltacoronavirus infects both mammals and avian species (Li, 2016; Jaiswal \& Saxena, 2020). SARS-CoV-2, which is responsible for the pandemic COVID-19 has been identified to be a member of $\beta$ genus (Yang \& Wang, 2020). Currently, six coronavirus strains that infect humans have been identified. The first four strains, i.e., 229E, OC43, NL63, and HKU1 were found to be broadly distributed among humans, and the other two strains, SARS-CoV and MERS-CoV were of zoonotic origin (Zhu et al., 2020) (Figure 1). Presently, SARS-CoV-2 strains are classified into two lineages, $\mathrm{L}$ and $\mathrm{S}$, that are well defined by two different SNPs at nucleotide 28,114 , i.e., L lineage: T28,114 is in the codon of leucine; S lineage: $\mathrm{C} 28,144$ is in the codon of serine that shows nearly complete linkage across the viral strains that have been sequenced to date (Dawood 2020; Tang et al., 2020a). Currently, SARS-CoV-2 isolates revealed that the spike protein (S) contains D614G is predominant, and this change has enhanced the virus transmission, as the $\mathrm{S}^{\mathrm{G} 614}$ is more stable and transmits more efficiently than the $S^{\text {D614 }}$ (Zhang et al., 2020a).

Table 1: Characterisation of SARS-CoV-2 virus

\begin{tabular}{|cc|}
\hline Order & Nidovirales \\
\hline Family & Coronaviridae \\
\hline Subfamily & Orthocoronavirinae \\
\hline Genus & Beta coronavirus \\
\hline Subgenus & Sarbecovirus \\
\hline
\end{tabular}

Source: (Almeida and Berry, 1968)

\section{Structural Biology and Proteomics of SARS-CoV-2}

All coronaviruses that have been reported share similar genomic construction and organization. Electron micrographic images of SARS-CoV-2 particles were generally found spherical with some pleomorphism and distinctive spikes, about 9 to $12 \mathrm{~nm}$. Diameter varied from about 60 to $140 \mathrm{~nm}$ and, like other coronaviruses, gave virions which characteristic appearance of a solar corona and the spike projections in the membrane gives the resemblance of a crown, or corona in Latin (Su et al., 2016; Zhu et al., 2020). The SARSCoV-2 possesses a single-stranded positive-sense RNA genome with a size ranging from 29.8 to $29.9 \mathrm{~kb}$ (Su et al., 2016; Dhama et al., 2020a; Khailany et al., 2020). The viral genome is consisting of 5'untranslated region (5'-UTR), 11 open reading frames (ORFs), and 3'-UTR. The 5'- two-thirds of the genome contains two large open reading frames (ORF1a and ORF1ab) coding for polyproteins (pp)1a and pp1ab, respectively, which are cleaved by the virus proteases to yield 16 non-structural proteins (Nsp1-Nsp16) (Yoshimoto, 2020). Nsp1 is known as the leader protein, which binds to the host 40S ribosome and selectively inactivates translation and cleaves host mRNA (Huang et al., 2011); Nsp2 of SARS-CoV is known to binds to host prohibitins 1 and 2, which are required for optimal mitochondrial morphology (Cornillez-Ty et al., 2009); Nsp3 is a papain-like protease that cleaves pp1a and pplab to yield mature non-structural proteins; mutation of the Nsp3 protein abolished viral replication (Sakai et al., 2017); Nsp4 interacts with Nsp3 and is essential for the virus replication (Sakai et al., 2017); Nsp5 is a cysteine-like protease of coronaviruses which is the major protease that cleaves the polyproteins to yield mature and intermediate nonstructural proteins (Tomar et al., 2015); Nsp6 induces membrane vesicle formation and expansion to autophagosome but limits autophagosome maturation (fusion with lysosome for content degradation) (Cottam et al., 2014); Nsp7, Nsp8 and Nsp12 form RNA polymerase complex (Gao et al., 2020; Yoshimoto, 2020); Nsp9 of coronaviruses interacts with cellular protein, i.e., DEADbox RNA helicase 5 (DDX5) important for virus replication (Zhao et al., 2015); Nsp10 forms complex with Nsp14; the latter is known to function as an S-adenosylmethionine-dependent (guanine-N7) methyl transferase (N7-MTase) (Ma et al., 2015; Yoshomoto, 2020); Nsp11 has $84.6 \%$ sequence identity to the Nsp12 which is the viral RNA-dependent RNA polymerase for genome replication and translation (Subissi et al., 2014).

The evolutionary studies and phylogenetic analysis of SARS-CoV-2 showed high similarity (>90\%) with other SARS viruses, and their RNA-dependent RNA polymerase (RdRp) could serve as a potential anti-coronavirus drug target (Aftab et al., 2020). Nsp13 is the virus helicase enzyme which unwinds duplex RNA (Jang et al., 2020); Nsp14 is 3'-5' exoribonuclease and N7-methyltransferase enzymes (Case et al., 2016); Nsp15 is coronavirus endoribonuclease that degrades the virus polyuridine sequences to evade activating host intracellular pathogen recognition receptors (PRRs) for avoiding innate anti-viral activity (Hackbart et al., 2020); Nsp16 interacts with Nsp10 to form RNA cap 2'-O-methyltransferase which promotes mRNA translation and prevents the viral RNA from being recognized by the host PRRs (Decroly et al., 2011). The remaining 3 '-one-third of the genome contains ORF2 (spike protein, S, that binds ACE2 receptor on the host cell for virus entry); ORF3a (ion channel protein related to NLRP3 inflammation activation, caspase 3 activation and interleukin-1 $\beta$ production); ORF4 (envelope protein, 


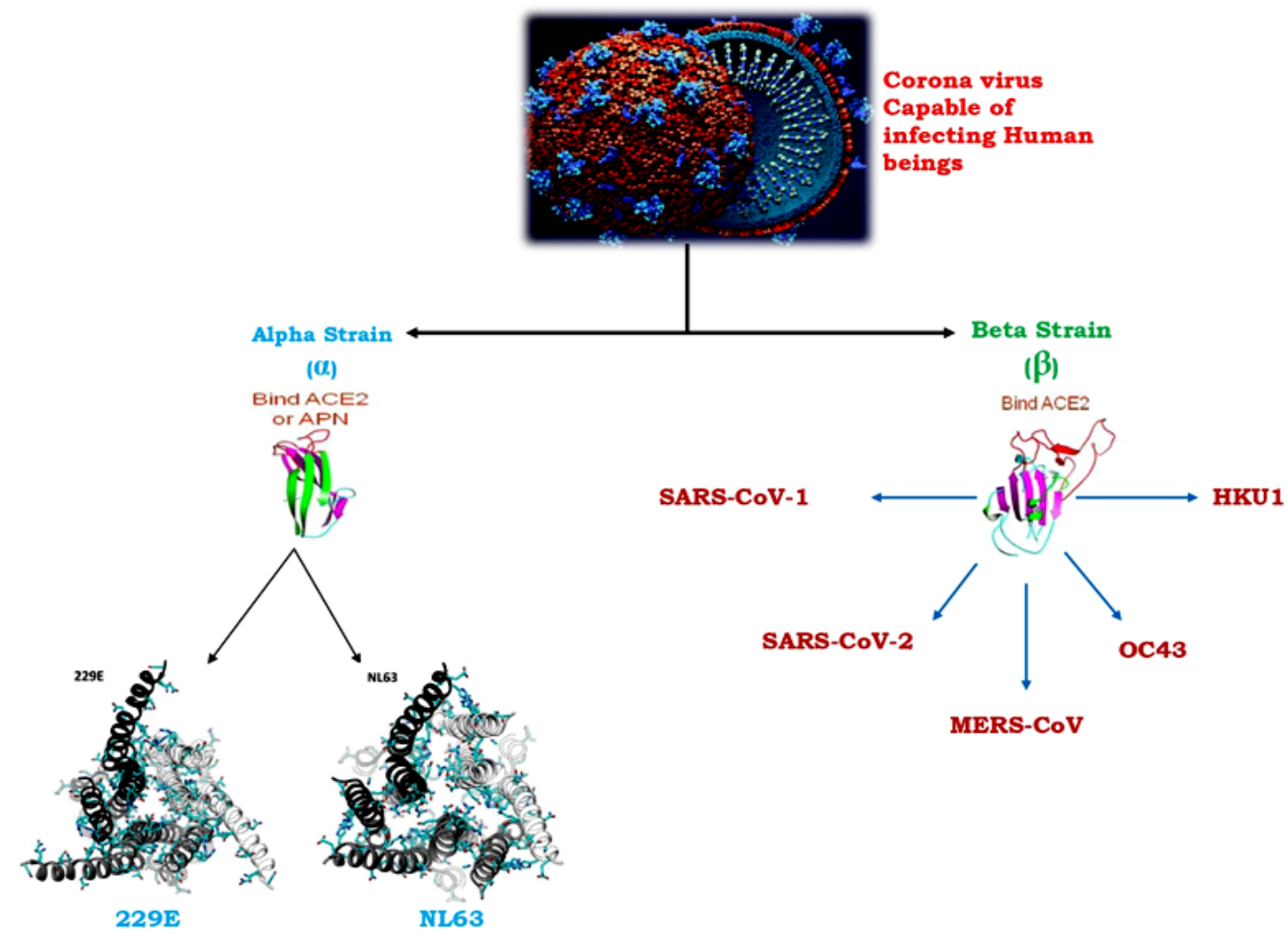

Figure 1 Strains of Corona virus Source: Authors, 2020

E, which is a small integral membrane protein that oligomerizes to form ion channel); ORF5 (membrane protein, M, which is an integral membrane protein that interacts with nucleocapsid phosphoprotein to encapsidate viral genome and plays a role in virus assembly and also cellular apoptosis); ORF6 (an accessory protein that plays a role in virus pathogenesis); ORF7a (accessory protein of unidentified function); ORF7b (an accessory protein found in Golgi compartment); ORF8 (probably plays a role in innate immune evasion); ORF9 (nucleocapsid phosphoprotein, N, that interacts with and encapsidates the viral genome for stability); and ORF10 (unknown function) (Yang \& Wang, 2020, Zhou et al., 2020a; Zhou et al., 2020b; Yoshimoto, 2020). As mentioned above, based on the genomic alignments, the researchers categorized SARS-CoV-2 into two types, namely $\mathrm{S}$ and $\mathrm{L}$ types, and they observed that $\mathrm{L}$ type was more aggressive and had a higher transmission rate than $\mathrm{S}$ type (Tang et al., 2020a).

The structure of SARS-CoV-2 virus has been shown in Figure 2. Three integral membrane proteins, namely the $\mathrm{S}, \mathrm{M}$, and $\mathrm{E}$ decorate the SARS-CoV-2 envelope. The immunogenic $\mathrm{S}$ protein comprises of S1 and S2 domains; the S1 contains receptorbinding domain (RBD) that has receptor binding motif (RBM) playing role as the virus ligand that binds to human angiotensin-

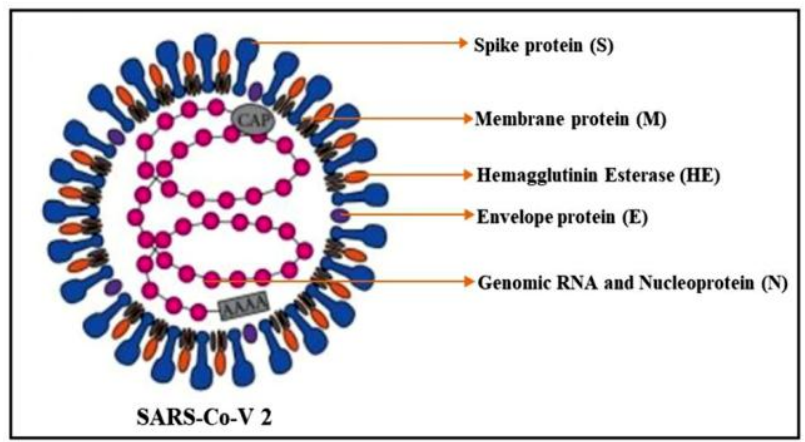

Figure 2: Structure of COVID-19 virus Source: Authors, 2020

converting enzyme 2 receptor (ACE2) for virus entry into the host cells (Ou et al., 2020; Panati \& Narala, 2020). The S2 domain is pivotal for the viral genome release for further replication in the host cytoplasm (Walls et al., 2020). The S protein has also been found to have a crucial role in determining the host range, tissue tropism, and also acts as the active inducer of the host immune response ( $\mathrm{Li}, 2016$; Yatoo et al., 2020). The E protein is being present in a negligible amount in the virions of SARS-CoV, but the amount of this protein increases in the cells after infection (Nal et al., 2005). The major functions of $\mathrm{E}$ 
protein involve morphogenesis, budding of the virus, and trading of the viral particles (Ye \& Hogue, 2007; Ruch \& Machamer, 2012a; Ruch \& Machamer, 2012b; Nieto-Torres et al., 2011). The $\mathrm{M}$ protein is the most abundant protein among the three structural proteins of coronavirus. It interacts with the S, E, and $\mathrm{N}$ proteins and functions in the virus assembly (Masters, 2006; Hogue \& Machamer, 2012; Ruch \& Machamer, 2012b). Both the $\mathrm{E}$ and $\mathrm{M}$ proteins are involved in virus assembly $(\mathrm{Li}, 2016)$ and the acquisition of virus envelope from the host cell membrane (Yang \& Wang, 2020). Nucleocapsid phosphoprotein (N) is associated with the viral genome, replication process, and the cellular response of host cells to viral infections (Astuti \& Ysrafil, 2020; Kim et al., 2020a; Kim et al., 2020b).

\section{Clinical manifestations of COVID-19}

Symptoms of COVID19 develop after 2 to 14 days of SARS-CoV-2 infection. Coronavirus infects the respiratory, nervous and gastrointestinal systems and adapts to the changing environment and also can adapt efficiently to the tissue tropism by mutation and recombination (Dhama et al., 2020b). Clinical features include chills, fever, fatigue, hypoxemia, which may quickly progress to acute respiratory distress syndrome (ARDS) (Dhama et al., 2020b; Wu et al., 2020a). The other symptoms include upper respiratory tract infections (URI), dry cough (with little sputum), myalgia, chest discomfort, dyspnea, abdominal pain, hemoptysis, muscle soreness and/or diarrhea. In some rare cases, rhinorrhea has been observed and in cases of severe illness, pneumonia, sore throat and ecchymosis were also evident. Increase in body temperature may be up to $38.1^{\circ} \mathrm{C}$, blood pressure of $129 / 68 \mathrm{~mm} / \mathrm{Hg}, 79$ to $92 / \mathrm{min}$ of heartbeat, 18 breaths/min of respiratory rate, mild increase in inflammatory cell infiltration over the bilateral lower lung field as revealed by chest radiography (CXR), peripheral white blood cell count of $\sim 3770 / \mathrm{mm}^{3}$ with $62.3 \%$ neutrophils and $32.1 \%$ lymphocytes (Huang et al., 2020; Lu, 2020a). There are neurological manifestations in some patients, including hyposmia (partial or complete loss of sense of smell), headache, weakness, altered consciousness. Encephalitis, demyelination, neuropathy, and stroke have also been noted in COVID-19 patients (Montalvan et al., 2020). Infected subjects may be asymptomatic or presented with only mild symptoms.

Persons who have any of the following comorbidities, such as cardiovascular disease (CVD), chronic kidney disease (CKD), hypertension and diabetes are at higher risk of illness due to modulated virus-host interactions and host-immune responses (Apicella et al., 2020; Arumugam et al., 2020; Baradaran et al., 2020; Lu et al., 2020b). Kidney damage has also been reported in COVID19 patients as SARS-CoV-2 can also particularly affect this important organ via direct tropism and indirectly by cytokine storm and other mechanisms, leading to acute kidney injury and higher mortality, though SARS-CoV-2 associated renal damage need to be

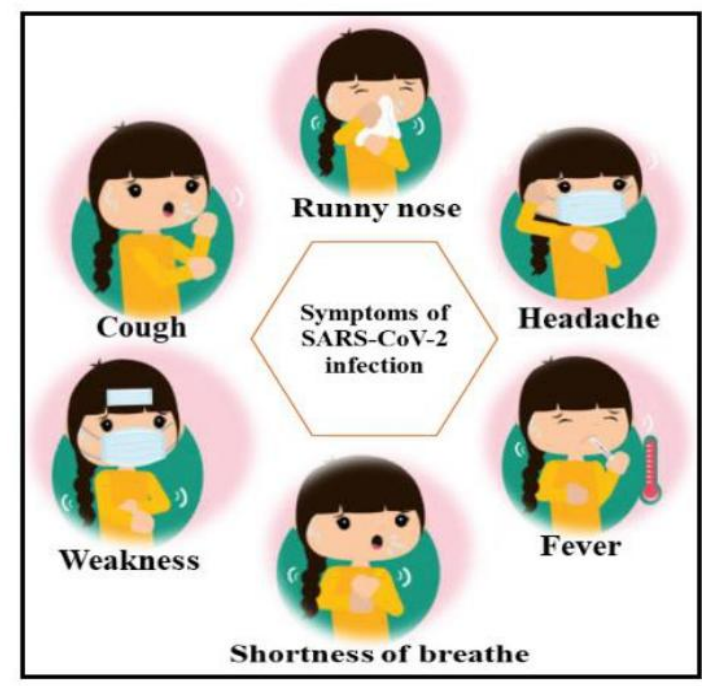

Figure 3 Sypmtoms of COVID-19 virus infection Source: Authors, 2020

explored further (Gabarre et al., 2020; Henry \& Lippi, 2020; Patel et al., 2020a; Ronco \& Reis, 2020). Other signs noted occasionally are pharyngalgia, nausea, headache, sore throat, vomiting, anosmia, and ageusia. Post-treatment signs can be cardiac arrhythmias, hypoglycemia, neuropsychiatric effects, including agitation, confusion, hallucinations and paranoia, and metabolic alterations. Some of the major symptoms of COVID-19 are shown in Figure 3.

Apart from the high potential of SARS-CoV-2 in compromising the respiratory system, its ability to involve many hosts and rapid transmission in case of severe infections make it a strong challenger for the immune system. The interaction of SARS-CoV-2 with host immune systems results in the production of a large number of cytokines, which determine the condition of the lungs of the patients (Nasab et al., 2020).

\section{Risk Factors for COVID-19}

The risk factors underlying the SARS-CoV-2 infection varies among the population around the world and COVID-19 progresses for a higher severity and fatality in patients with advanced age along with any of the co-morbidities such as hypertension, blood pressure, type 2 diabetes mellitus (T2DM), hyperglycemia, heart diseases, chronic lung, kidney and liver diseases, cerebrovascular disease, and cancers as well as overweight, obesity, and smoking background (Adamo et al., 2020; Apicella et al., 2020; Baradaran et al., 2020; Bornstein et al., 2020; Chen et al., 2020a; Liu et al., 2020b; Qiu et al., 2020; South et al., 2020; Wang et al., 2020a; Wu et al., 2020a; Yang et al., 2020a; Zhou et al., 2020b). Smokers are more susceptible to respiratory viruses. The ACE2 receptor can be upregulated by smoking, which serves as a receptor for both SARS coronavirus and the human respiratory coronavirus NL638. Electronic smoking 
devices can also serve the purpose (Brake et al., 2020). Based on gender, males are more prone to SARS-CoV-2 infection, as women have lesser ACE2 receptors, and the protection of X chromosome and sex hormones might make women less suspectable to SARSCoV-2 infection since those play a major role in innate and adaptive immunity (Jin et al., 2020; Jordan, 2020; Yang \& Wang, 2020; Zheng et al., 2020). The younger children, the elderly, and the immunocompromised persons are at higher risks for SARS-CoV-2 infection and its fatal outcomes (Abbatecola \& Antonelli-Incalzi, 2020; Dhama et al., 2020c; Jordan, 2020; Liu et al., 2020c; NikolichZugich et al., 2020). There are risk factors for different settings like individual settings, healthcare settings, quarantine personnel's, and community settings (CDC 2020; Chou et al., 2020). Persons with frequent exposure to infected personnels like the medical staff are always at increased risk. Those involved in crowded places, public gatherings, and having routine public dealings like essential stores, transport authorities, air staff, banking persons etc. are also at increased risk.

\section{Stages of COVID-19}

There are three stages of COVID-19 as follows:

1. Stage I: An asymptomatic incubation period; diagnosed in the patients with or without detectable virus; the asymptomatic transmission of the virus occurs

2. Stage II: Non-severe symptomatic period with the presence of the virus, patient's exhibit mild symptoms like high fever, cough, and mild dyspnea.

3. Stage III: Severe respiratory symptomatic stage with high viral load.

Different stages of the spread of virus

1. Stage I: Stage where only those who have traveled to virus affected countries test positive
2. Stage II: Local transmission from existing positive cases

3. Stage III: Community transmission where the mass of people get affected

4. Stage IV: Epidemic condition widespread occurrence of disease (Figure 4).

\section{Transmission of COVID-19}

The respiratory passage has been the prominent route of transmission with novel evidence suggesting possible gastrointestinal transmission also. Most possible modes of transmission are via droplet transmission from an infected individual and also through fecal-oral transmission, mainly from asymptomatic carriers. Additionally, fomite has led to rapid transmission worldwide. The virus has been detected in gastric mucosa, stool, urine and saliva (Guan et al., 2020). An electron microscopic image of SARS-CoV-2 virus from stool samples of COVID-19 infected patients who had no diarrhealike symptoms confirmed that it is being transmitted from asymptomatic carriers to others. The patients, who were positive for COVID-19 from stool samples showed negative with that of respiratory samples (Hindson, 2020). The transmission from the respiratory droplet that was assumed to propagate in the air at a distance longer than 1 meter is limited since these droplets were heavy to hang in the air and they tend to fall-off on the surfaces or floors and then, by touching those contaminated surfaces (fomite) and contacting the nose, eyes or mouth, one gets the virus. It is uncertain how long the virus can sustain in the air or surfaces, but the preliminary report suggests that it may persist on the surfaces for a few hours to several days. The importance of air-borne route of SARS-CoV-2 transmission as the dominant route of the virus spread needs to be taken care and adequate social distancing of 6 feet $/ 2$ meters or more may be followed to avoid virus transmission from an infected person. Personal biosafety precautions, including wearing face masks are warranted for checking the spread of virus from a contaminated environment (Morawska \& Cao, 2020; Zhang et al., 2020b). Small particles loaded with viruses may diffuse up to 10

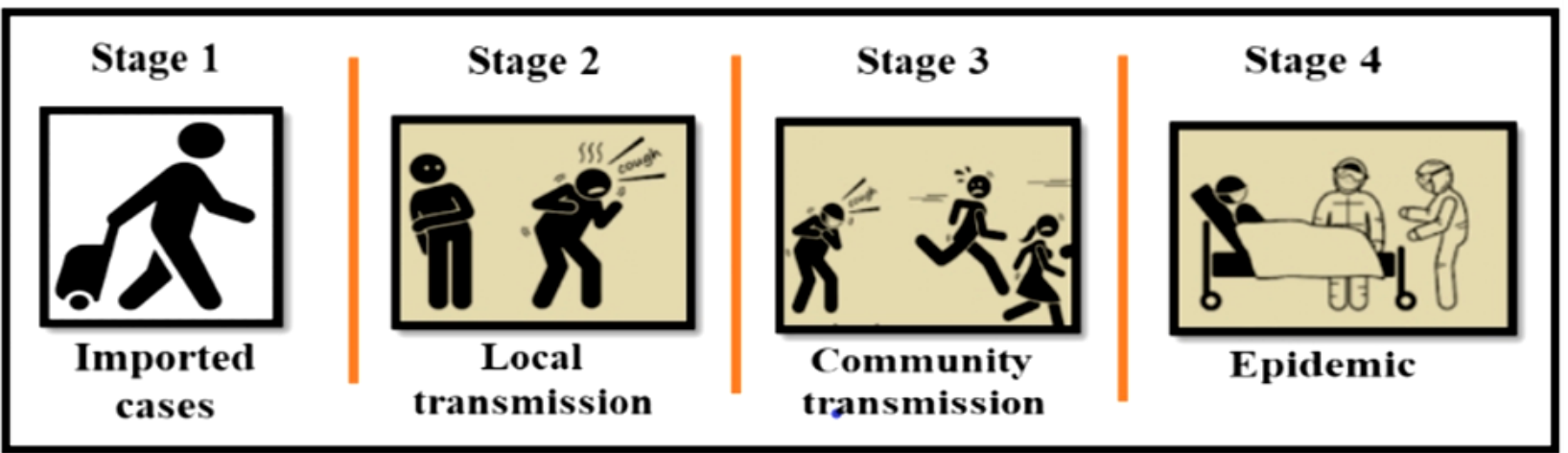

Figure 4 Stages of spread of COVID-19 virus Source: Authors, 2020

Journal of Experimental Biology and Agricultural Sciences http://www.jebas.org 
meter-distance from infectious sources, which may give rise to potent aerosol transmission of SARS-CoV-2 (Setti et al., 2020).

Even though the SARS family of coronavirus was common in animals, the new SARS-CoV-2 has no confirmed evidence for its association with animals, though implications of its origin with bats, panglolins have been revealed and virus has been reported from animals such as cats, dogs, tigers, lions, and minks, and this was reported as a human-to-human transmissible virus (Dhama et al., 2020a; Tiwari et al., 2020). The incubation period for COVID-19 is 2-14 days (Panati \& Narala, 2020). SARS-CoV-2 can survive on various non-living/inanimate articles for variable periods (van Doremalen et al., 2020). In aerosols, it can remain up to 3 hours. The virus is more stable on plastic and stainless steel than on copper and cardboard, and a viable virus was found up to 72 hours (van Doremalen et al., 2020).

The recent reports regarding the presence of SARS-CoV-2 RNA in sewage and wastewater indicate high global health concerns and further epidemiological studies are needed to investigate the possibility of water-borne route of transmission by wastewater-based epidemiology and sewage surveillance to be performed (La Rosa et al., 2020; Lodder \& de Roda Husman, 2020). In-depth evaluation of the SARS-CoV-2 environmental survival and persistence, the feasibility of water-borne and fecal-oral transmissions need to be carried out to design appropriate and time disease prevention and control strategies (Bonato et al., 2020; Ding \& Liang, 2020; Hart \& Halden, 2020; Orive et al., 2020; Quilliam et al., 2020).

Evidences of survival and stability on surfaces and objects for quite some time and recent isolation of its genetic material from frozen products can alarm for chances of other modes of transmission through these explorations are still in infancy and require drastic scientific investigations for proper proof.

\section{Animal Linkages, Spillover and Zoonotic Implications}

SARS-CoV-2 has been thought to have its origin from animals. The viral studies revealed animal linkages, spillover events, jumping the cross-species barrier and zoonotic concerns owing to human-animal interfaces (Dhama et al., 2020a; Dhama et al., 2020d; Ji et al., 2020; Murdoch \& French, 2020; Rodriguez-Morales et al., 2020a; Salata et al., 2020; Tiwari et al., 2020). Apart from the hypothesis of SARS$\mathrm{CoV}-2$ being originated from bats and pangolins, and other animals being explored to find out its intermediate host, the recent findings of the presence of SARS-CoV-2 infection in companion, pet and zoo animals including cats, dogs, tigers, lions and minks have raised high concerns, and need to be investigated for zoonotic sources of COVID-19 (Dodds, 2020; Hobbs \& Reid, 2020; Jo et al., 2020; Shi et al., 2020a; Mallapaty, 2020; Oreshkova et al., 2020; Sharun et al., 2020a; Sit et al., 2020; Tiwari et al., 2020). The ferrets, cats, and primates have also been found to be susceptible animals for SARS-
CoV-2 (Gollakner \& Capua, 2020; Shi et al., 2020a). In this context, surveillance and monitoring of SARS-CoV-2 in these animals as well as in other livestock animals and wildlife species and their handlers must be strengthened while adopting appropriate one health approach, public health measures and necessary preventive and control strategies to check this pandemic virus in a better way (Dhama et al., 2013a; Bhatia, 2020; Dodds, 2020; FAO, 2020a; FAO, 2020b; Leroy et al., 2020; McNamara et al., 2020; Murdoch \& French, 2020). Dyal et al. (2020) have also emphasized that necessary precautions need to be taken up by workers associated with meat and poultry processing industries to protect them from SARS-CoV-2 infection as well as to aid the production of safer poultry meat and meat products.

The main reason for spillover and the cross-species jumping is the epidemiological sustenance or persistence in the animals so that virus pathogen can survive in its hosts. Adaptation within-host enables survivability without affecting the host, development of immunity can lead to expulsion from the host and poor stability or survivability in the outside environment can lead to evolutionary extinction. Hence, CoVs tend to involve numerous animal hosts for persistence and occasional human infections or disease outbreaks.

\section{Diagnosis}

From the initial clinical examination, radiographic imaging [X-ray, computed tomography (CT) scan, ultrasound] to current advances including molecular diagnostics [real-time reverse transcriptionpolymerase chain reaction (RT-PCR), enzyme-linked immunosorbent assay (ELISA), genome sequencing, loop-mediated isothermal amplification (LAMP)] are being employed, and by such advances, the diagnosis of COVID-19 has come across a long way for better specificity and sensitivity (Dhama et al., 2020a; Dinnes et al., 2020). Nasal, nasopharyngeal and oropharyngeal swabs are appropriate samples for SARS-CoV-2 testing (Huang et al., 2020). The CT scan of human airway epithelial cells of patients affected with COVID-19 showed the extracellular (free) virus particles and inclusion bodies filled with virus particles in membrane-bound vesicles in the cytoplasm (Zhu et al., 2020). Chip-based isothermal amplification analyser, immunoglobin $\mathrm{M}$ and $\mathrm{G}$ assay kits, and reverse transcription-polymerase chain reaction (RT-PCR) assay kits that target the RNA-dependent RNA polymerase (RdRp)/helicase (Hel), S protein and $\mathrm{N}$ protein genes of SARS-CoV-2 have been developed (Vashist, 2020; Zhai et al., 2020). The viral nucleic acids assays are currently used for confirmation of COVID-19 (Guan et al., 2020). In India, at present, the RT-PCR technology is being used for the diagnosis and has been regarded as the confirmatory test for COVID-19.

The global shortage of biological reagents and molecular diagnostic kits pose a major bottleneck and necessitate the implementation of cost-effective planning for diagnosing COVID-19, particularly in 
case of increased demand of SAS-CoV-2 detection in a few severely affected developing countries through optimizing RT-PCR test by employing pooled sample testing while maintaining clinical sensitivity and enhancing large-scale implementation of this pandemic virus testing (Ben-Ami et al., 2020; Farfan et al., 2020). RNA extraction-free protocol for detection of SARS-CoV-2 [in fresh samples (storage <1 week)] via rapid RT-qPCR has also been reported recently, which is a faster, reliable and cost-effective test; such rapid tests would aid in effective COVID-19 pandemic control program by providing early testing results (Lübke et al., 2020).

For auxiliary diagnosis, SARS-CoV-2 antigen detection reagents have also been successfully developed and applied (Yang et al., 2020b). Serological tests are also being developed and evaluated for use in the diagnosis of COVID-19 (FDA 2020). Rapid antigen-based tests and serological tests employing use of antibodies have their advantages of quick detection, multiplexing at one time, automatization and they can guide the ways in predicting the epidemiology of disease and in vaccine development. Though the requirement of skilled personnel, at times false-negative results either because of less or inconsistent viral titer in the collected sample and/or the variability in sampling along with pre-requisite of standard dedicated (BSL-2) laboratories are some limitations for large scale testing and hence the development of chip-based serological tests and POCT kits are need of the current time (Carter et al., 2020; La Marca et al., 2020; Tang et al., 2020b). In pursuance of the lab to land techniques, on-chip ELISA has been developed for fast diagnosis of SARS-CoV-2 infected or exposed persons in hospitals, health-care settings, residential colonies, at the airport and various crowd-expected places. By the use of on-chip ELISA, patient's antibodies (IgG/IgM) against SARS-CoV-2 can be detected in the blood plasma of the COVID-19 patient. For this, micro-device capable of separating plasma from the blood is designed to detect the presence of antibodies in the plasma. This will certainly help in epidemiological screening of COVID patients by sero-monitoring (Tripathi \& Agrawal, 2020). Cellex Inc. company has manufactured and launched qSARS-CoV-2 IgG/IgM rapid antibody test based on lateral immunoassay and It has been approved by the FDA with the status of Emergency Use Authorization (EUA) (Hinton, 2020). The National Institute of Virology, Pune has developed "COVID Kavach ELISA" based on antibody detection in the patients. It is approved by the ICMR and a worldwide renowned company Zydus Cadila is producing this ELISA kit at a large scale in India (Combating COVID-19: NIV-Pune Develops India's First Antibody Testing ELISA Kit, Health News, ET Health World; Konwar \& Borse, 2020).

Other many advances in diagnosis have been exploited for the detection of SARS-CoV-2 (Ai et al., 2020; Cheng et al., 2020; Dhama et al., 2020a; Dinnes et al., 2020; Udugama et al., 2020; Vashist, 2020; Yang et al., 2020b). Researchers have developed label-free electrochemical transduction based hand-held portable device for detecting COVID-19-specific viral RNA/c-DNA (Tripathy \& Singh, 2020), include next-generation sequencing (NGS), phylogenetic analysis (Malik et al., 2020a), multiplex assays (Zhang et al., 2020c), interactive web-based dashboard (Dong et al., 2020), Lateral flow immunoassay (LFIA) based point-of-care detection systems, CRISPR-based SHERLOCK (Specific High Sensitivity Enzymatic Reporter UnLOCKing) technique, CRISPRbased diagnostics including lateral flow assay (Ai et al., 2020; Broughton et al., 2020; Hou et al., 2020), artificial intelligence (AI) (Li et al., 2020a), loop-mediated isothermal amplification (LAMP) (Hu et al., 2020; Lu et al., 2020c; Yu et al., 2020), home-based pointof-care testing (POCT), tracking and mapping of SARS-CoV2/COVID-19 by using geographical information systems (GIS softwareKosmo® 3.1), web-based real-time dashboards, apps and modern platforms of information technology (Arab-Mazar et al., 2020; Kamel Boulos \& Geraghty, 2020; Lin et al., 2020; Dhama et al., 2020a).

From swab specimens, the virus is detected by RT-PCR, but as it is a time-consuming technique, hence use of field-effect transistor (FET) -based biosensor is advised. As point-of-care testing, field-effect transistor (FET)-based biosensors are comparatively faster to detect SARS-CoV-2 virus with high sensitivity in nasopharyngeal swab samples (Seo et al., 2020; Tripathi \& Agrawal, 2020). For direct detection of SARS-CoV-2 virus in saliva samples, a plasmonic fiberoptic absorbance biosensor has been developed as another portable biosensor that can easily and precisely diagnose the presence of the virus without investing much time on sample processing (Murugan et al., 2020). Optical fiber sensors based on evanescent wave absorbance and localized surface plasmon resonance have been made to speed-up the screening of COVID-19 (Nag et al., 2020).

At the face of a pandemic, various telecommunication systems are also keeping eyes and are offering various Apps on smartphones (enabled with $4 \mathrm{G} / 3 \mathrm{G}$ ) and feature mobiles (2G phones) for monitoring and indirect assessment of risks of acquiring infection in a person from another COVID-19 infected person, present in proximity through mobile GPS and Bluetooth. In a country like India with a grand population of approximately 1.38 billion, more than ten million people have downloaded the Aarogya Setu App, designed for Android and IoS Smartphone holders to have a watch on the spread of disease and presence of COVID-19 patients even in the area of 1 kilometer. With the combined efforts of the Indian Prime Minister's Principal Scientific Advisor, Prime Minister's Office, Ministry of Electronics and Information Technology (MEITY), Ministry of Telecom, Ministry of Health, various state governments and researchers, Aarogya Setu App has been developed and launched officially to have an idea of the spread of SARS-CoV-2 in any region, locality or area of $1 \mathrm{~km}$ to 10 kilometers (Jhunjhunwala, 2020). Likewise, other Apps as Bihar Saathi and CG COVID-19 
have also been developed to advise social distancing, screen containment zones and help supervise the movement of infected patients (Mallik et al., 2020a). Such android mobile Apps also record the movement of ambulances carrying COVID-19 infected patients over Google maps to help traffic police to arrange the uninterrupted passage to the vehicle on a priority basis by maintaining the distance from other vehicles (Mallik et al., 2020b). Among a variety of symptoms appeared, one seen in few COVID-19 patients is the loss of senses to aroma/odour due to inability to smell, that's why one olfactory device working with a mobile app has been recently developed for pre-screening and detection of the level of olfactory senses digitally and accurately in the contactless mode in suspected, exposed and/or confirmed COVID-19 patients (Gandhi et al., 2020).

Evidences revealed that the spreading rate of SARS-CoV-2 is very fast. Therefore quick tracing, testing and treatment policy must be followed to counter the deteriorating health effects of COVID-19. At this time, the combined responsibility of technologists and researchers is to invent new diagnostic Apps, models and micro devices or repurpose available techniques of molecular and serological fronts like RT-PCR, LAMP, ELISA, point-of-care rapid handy diagnostics and advanced tools and techniques, while taking into due account their advantages, limitations and challenges (Afzal, 2020; Agrawal \& Singh 2020; Dhama et al., 2020a; Dinnes et al., 2020; Premraj et al., 2020; Tang et al., 2020b; Wu et al., 2020b). Appropriate biosafety measures should be adopted during the collection, transportation and testing of COVID-19 samples (Karthik et al., 2020).

\section{Advances in Vaccines, Treatment and Management of COVID-19}

Therapeutic management of COVID-19 patients have relied mainly on symptomatic presentation of cases and utilisation of available drugs against other viral pathogens along with supportive therapies and care, whereas general preventive measures have been incorporated in prophylactic management. Presently, there is no definitive vaccine or specific anti-viral drug regime to treat critically ill patients affected by SARS-CoV-2. Numerous efforts are being made to develop effective drugs, therapeutics and prophylactics against COVID-19 with some showing promising results and some in final stages of development (Dhama et al., 2020a; Dhama et al., 2020e; Guo et al., 2020; Lu, 2020b; Wu et al., 2020c; Yatoo et al., 2020). Early diagnosis, isolation and provision of supportive care that aids in the management of COVID-19 infected patients, e.g., oxygenation, mechanical ventilation, and fluid management are effective in saving the lives of patients (Li et al., 2020b; Guan et al., 2020). Supplementation of low dose systematic corticosteroids and atomization of interferon has been encouraged as a combination treatment for critical COVID-19 management. Interferon nebulization has proven quite effective in few studies (Shen et al., 2020). Passive immunization of convalescent plasma has been proved by meta-analysis to treat related coronaviruses such as SARS-CoV and MERS-CoV and also China National Biotec Group $\&$ Co. has claimed that immunoglobin therapy improved the oxygenation and reduced viral load (Cunningham et al., 2020; Li et al., 2020b). In the case of severely ill patients, intravenous immunoglobulin (IVIG) and low molecular weight heparin (LMWH) has prevented coagulation and inflammation, which also helps in preventing other organs, heart, and kidney from becoming worse and to prevent from mild to severe or critically ill condition. The intermittent short-term hemofiltration (ISVVH), low-dose, shortcourse glucocorticoid therapy were also found helpful (Cunningham et al., 2020; Li et al., 2020b). Currently, the management of COVID19 was expected to be attained by improving personal protection and hygiene management at community levels.

Repurposing of available anti-virals is a fruitful strategy against SARS-CoV-2, as being a new virus currently, no vaccines are available (Asai et al., 2020; Santos et al., 2020). Certain antiviral medications that have been prescribed for treatment of COVID19 namely remdesivir, chloroquine, umifenovir, loparinir/ ritonavir, camostat mesylate and favipiravir were under in vitro clinical trial and additionally, researchers have organized clinical trials for the study of the antiviral drugs such as kaletra, arbidol, hydroxychloroquine (hcq), darunavir, lianhua qingwen granules and shuanghuanglian oral liquid (Devaux et al., 2020; Keni et al., 2020; Lu, 2020b; Meo et al., 2020; Sahraei et al., 2020; Vellingiri et al., 2020; Wang et al., 2020b). Along with ribavirin, corticosteroids helped to reduce incidences of mortality (Zhong et al., 2020a). Oseltamivir, teicoplanin, and $\beta$-D-N4hydroxycytidine are some other anti-virals being explored in COVID-19 (Baron et al., 2020; Lu, 2020b; Sheahan et al., 2020).

Functional capacity of kidney and liver varies in the patients of COVID-19 as it affects a range of age groups, therefore a combination of therapeutics along with immunopotentiating agents should be provided (Zhang et al., 2020d). As per the condition of ill patient, as part of therapy including anti-virals and compounds like ascorbic acid, azithromycin, epoprostenol, sirolimus, nitric oxide, IL-6 antagonists and interleukin associated therapies as means of the supportive package were found useful in combating the horrific episodes of COVID-19 (Waqas et al., 2020; Wu et al., 2020c). The use of corticosteroids as a reclamation treatment need explorative studies, it may lead to exacerbation of symptoms (Guan et al., 2020; Panati \& Narala, 2020; Zha et al., 2020). But few findings suggest that the usage of methyl prednisolone (corticosteroid) treatment may be useful for the treatment of the patients, who developed acute respiratory distress syndrome (ARDS) during SARS-CoV-2 progression (Wu et al., 2020c). Recently, dexamethasone, has proved a lifesaving drug for severely affected COVID-19 patients on ventilation and oxygen, alleviating cytokine storm and protecting lungs damage (Ledford, 2020; Patel et al., 2020b). 
Table 2: Potential therapeutic options

\begin{tabular}{|c|c|c|c|}
\hline $\begin{array}{l}\text { Potential } \\
\text { therapeutics }\end{array}$ & Drugs & Clinical uses & Reference \\
\hline $\begin{array}{l}\text { Antiviral and } \\
\text { anti- } \\
\text { inflammatory } \\
\text { combined } \\
\text { therapy }\end{array}$ & $\begin{array}{c}\text { Anti-inflammatory } \\
\text { drugs - Baricitinib (NAK and JAK } \\
\text { inhibitor) and fedratinib, ruxolitinib (JAK } \\
\text { inhibitor) combined with antiviral drugs } \\
\text { such as lopinavir or ritonavir and } \\
\text { remdesivir }\end{array}$ & $\begin{array}{ll}\text { - } & \text { inhibit Catherin mediated endocytosis } \\
\text { - } & \text { reduce virus infectivity, } \\
\text { - } & \text { virus replication, } \\
& \text { host inflammatory response }\end{array}$ & $\begin{array}{l}\text { (Tobaiqy et al., } \\
\text { 2020) }\end{array}$ \\
\hline $\begin{array}{l}\text { Antimalarial } \\
\text { therapy }\end{array}$ & $\begin{array}{l}\text { Chloroquine } \\
\text { Hydroxychloroquine }\end{array}$ & $\begin{array}{l}\text { - } \quad \text { inhibit replication of viruses } \\
\text { immune modulatory effects suppressing } \\
\text { the production and release of TNF- } \alpha \text { and } \\
\text { IL-6 } \\
\text { - } \quad \text { an autophagic inhibitor }\end{array}$ & $\begin{array}{l}\text { (Geleris et al., 2020; } \\
\text { Meo et al., 2002) }\end{array}$ \\
\hline $\begin{array}{l}\text { Convalescent } \\
\text { plasma therapy }\end{array}$ & Nil & $\begin{array}{l}\text { - } \quad \begin{array}{l}\text { antibodies from the convalescent plasma } \\
\text { suppress viraemia }\end{array} \\
\text { a }\end{array}$ & (Chen et al., 2020b) \\
\hline $\begin{array}{l}\text { Antiviral } \\
\text { therapy }\end{array}$ & $\begin{array}{c}\text { Ritonavir } \\
\text { Remdesivir } \\
\text { Ribavirin } \\
\text { Lopinavir } \\
\text { Oseltamivir } \\
\text { Penciclovir / Acyclovir }\end{array}$ & $\begin{array}{ll}\text { - } & \text { protease inhibitors } \\
\text { - } & \text { interfering with post entry of virus } \\
\text { immune modulation }\end{array}$ & $\begin{array}{l}\text { (Lu 2020b; Wang } \\
\text { et al., 2020b; Yao } \\
\text { 2020) }\end{array}$ \\
\hline $\begin{array}{c}\text { Herbal } \\
\text { treatments } \\
\text { (Chinese Herbal } \\
\text { Medicine) }\end{array}$ & $\begin{array}{l}\text { Astragali radix (Huangqi), Glycyrrhizae } \\
\text { radix Et Rhizoma (Gancao), } \\
\text { Saposhnikoviae radix (Fangfeng), } \\
\text { Japonicae flos (Jinyinhua) and } \\
\text { Forsythiae fructus (Lianqiao) }\end{array}$ & $\begin{array}{ll}\text { - } & \text { antiviral, } \\
\text { - } & \text { anti-inflammatory } \\
\text { - } & \text { treating upper respiratory tract infection }\end{array}$ & $\begin{array}{c}\text { (Chandra and } \\
\text { Rawat, 2015; } \\
\text { Gangal et al., 2020) }\end{array}$ \\
\hline $\begin{array}{l}\text { Indian } \\
\text { Medicinal } \\
\text { Plants }\end{array}$ & $\begin{array}{l}\text { Andrographis paniculata, Curcuma } \\
\text { longa, Glycyrrhiza glabra, Tinospora } \\
\text { cordifolia Withania somnifera, Zingiber } \\
\text { officinale, Tinospora cordifolia }\end{array}$ & $\begin{array}{ll}- & \text { antiviral } \\
- & \text { respiratory infection } \\
\text { - } & \text { anti-inflammatory } \\
\text { - } & \text { immunomodulaotry effects }\end{array}$ & $\begin{array}{l}\text { (Gangal et al., 2020; } \\
\text { Sinha et al., 2020; ) }\end{array}$ \\
\hline $\begin{array}{l}\text { Nutrients } \\
\text { (Vitamins) }\end{array}$ & $\begin{array}{l}\text { Vitamin C } \\
\text { Vitamin D }\end{array}$ & $\begin{array}{ll}\text { - } & \text { respiratory infection } \\
\text { - } & \text { antiviral } \\
\text { - } & \text { anti-inflammatory } \\
\text { immunomodulatory }\end{array}$ & $\begin{array}{l}\text { (Kim et al., 2020; } \\
\text { Caccialanza et al., } \\
\text { 2020; Carr, 2020; } \\
\text { Infusino et al., } \\
\text { 2020) }\end{array}$ \\
\hline
\end{tabular}

Novel therapeutic approaches may include, the discovery of spikebased vaccine, inhibition of transmembrane protease serine 2 (TMPRSS2) activity, blocking the ACE2 receptor, delivering an excessive soluble form of ACE2 (Zhang et al., 2020e). So far the therapeutics being employed in management of COVID-19 have been broad spectrum anti-virals, anti-inflammatory and antipyretics agents, antibiotics, oxygen inhalation, cytokines and convalescent sera (Dhama et al., 2020a; Stebbing et al., 2020; Tobaiqy et al., 2020; Yatoo et al., 2020) with few novel therapeutics being explored with continuous progress like hydroxychloroquine (Geleris et al., 2020), ivermectin (Caly et al., 2020), etc. Table 2 depicts the potential therapeutic options for coronavirus infections.

Antibody-based immunotherapeutics (neutralizing antibodies, monoclonal antibodies, tocilizumab, sarilumab, anakinra and intravenous immunoglobulin), natural killer (NK) cells, convalescent plasma and immunomodulatory approaches have also shown proven fruitful results for curing COVID-19 patients (Alijotas-Reig et al., 2020; Casadevall \& Pirofski, 2020; Chen et al., 2020b; Keam et al., 2020; Kumar et al., 2020; Market et al., 2020; Shanmugaraj et al.,
2020; Sharun et al., 2020b). Tocilizumab and baricitinib were used to control the excessive production of cytokines and interleukins in response to SARS-CoV-2 viral infection to hamper the intensity and side-effects of cytokine storm over the body of COVID-19 patients. Timely administration of such recombinant humanized antibody is proved to cut-down the rate of mortality in COVID-19 ill patients as they bind to IL-6 (Zhang et al., 2020f).

High efforts for developing potent vaccines, drugs/medicines, and therapies against COVID-19, limiting the spread of SARS-CoV-2, few are now under clinical trials (Ciotti, 2020; Dhama et al., 2020e; Keni et al., 2020; Malik et al., 2020b; Prompetchara et al., 2020; Yatoo et al., 2020). The potent SARS-CoV-2 vaccine candidates presently explored are comprised of mRNA, DNA, subunit, vectored and virus-like particles (VLPs) vaccines along with inactivated and attenuated vaccines. Artificial intelligence, CRISPR techniques, bioinformatics, structure-based drug designing, and large-scale compound repurposing are also being exploited for designing vaccines and therapeutic regimens to tackle SARS-CoV-2 (Abbott et al., 2020; Ahuja et al., 2020; Riva et al., 2020; Omolo et al., 2020). 


\section{Plants-Based Products and Herbs Against SARS-CoV-2}

Plants and herbal products have been known for ages as immunomodulatory agents and curing several ailments and diseases (Tan \& Vanitha, 2004; Dhama et al., 2018a; Tiwari et al., 2018). Plant products could be used as nutritional supplements to immunomodulators and act as preventive and treatment medicines, as well as antiviral agents that can be used in masks, as a disinfectant for surface sterilization, or as disinfectants to curb aerosol transmission of the virus (Panyod et al., 2020). Plants have the potential to produce antiviral agents, protective antibodies, immunomodulatory agents, vaccine candidates or help in the production of plant-based COVID-19 vaccines (Tiwari et al., 2009; Dhama et al., 2013b; Tiwari et al., 2018; Dhama et al., 2018a; Capell et al., 2020; Panyod et al., 2020; Rosales-Mendoza et al., 2020; Sinha et al., 2020; Weng, 2020). Molecular farming and transient expression systems of plant-based vaccine technology could provide vaccine candidates of plant origin and production of antigens resembling SARS-CoV-2, which can help in developing prophylactic modalities and immunomodulatory agents (Capell et al., 2020; Yao et al., 2020).

Plant-based phytochemicals found to be active against SARS-CoV-2 include essential oils, phenolic, alkaloids, peptides and others (Jahan $\&$ Onay, 2020). They can have numerous mechanisms of action ( $\mathrm{Li}$ et al., 2020c; Li et al., 2020d; Mani et al., 2020). These can have a direct effect on viruses, affect proteins, enzymes, or genetic material or can affect host receptors, proteins or mechanisms of viral attachment, entry or replication. Some anti-SARS-CoV-2 mechanisms are increasing endosomal $\mathrm{pH}$, immune-modulating, interfering with terminal glycosylation of the cellular receptor, ACE2, interacting with both cellular membranes and with viral and/or cellular proteins, blocking virus entry by specifically inhibiting the activity of cathepsin $\mathrm{L}$ thereby preventing the release of viral RNA and the continuation of the virus replication cycle, inhibiting 3CL-pro (major viral protease), increasing autophagolysosomes, and affecting the autophagic flux, and so on (Li et al., 2020c; Li et al., 2020d). Their antiviral effects can help in therapeutic developments to counter COVID-19 (Jahan \& Onay, 2020). Synergism of plant-based molecules with other drugs can aid the antiviral effects against SARS-CoV-2 (Prasad et al., 2020).

The extracts of the following herbal evergreen shrub, provided potent inhibition of SARS-associated coronavirus: the aromatic shrubs include Lycoris radiata (red spider lily), Pyrrosia lingua (a fern), Artemisia аппиа (sweet wormwood) and Lindera aggregate (Li et al., 2005). The use of these aromatic oils for air sterilization needs to be studied for standardization of minimum inhibitory concentration.

Plants and their extracts and herbs have shown promising antiviral potential and immune enhancing activities for several deadly emerging and re-emerging human viral pathogens including SARSCoV, Zika virus, Ebola virus, Nipah virus and others (Swamy et al., 2016; Munjal et al., 2017; Dhama et al., 2018a; Dhama et al., 2018b; Tiwari et al., 2018; Singh et al., 2019; Mani et al., 2020). Besides making efforts to develop vaccines, therapies and antiviral drugs/medicines, the antiviral modalities of various plants and herbal products need to be exploited and propagated by incorporating more researches and performing desired experimentations, clinical trials and validation studies to fight against COVID-19 pandemic (Li et al., 2005; Li et al., 2020c; Chen et al., 2020c; Dhama et al., 2020a; Gangal et al., 2020; Malik et al., 2020b; Rastogi et al., 2020; Vellingiri et al., 2020; Yang et al., 2020c; Zhang et al., 2020g).

\section{Dietary Nutrition against SARS-CoV-2 Infection}

COVID-19 pandemic is a revolutionary period for the high research in nutritional science, healthy food items and adopts dietary intervention strategies for improving COVID-19 outcome and to protect the health of humans (Mozaffarian et al., 2018; Wu et al., 2019; Messina et al., 2020; Panyod et al., 2020). WHO is encouraging the research institutions to select traditional medicine products to be tested for clinical efficacy and safety for COVID-19 treatment. Especially when a specific cure is not available, the importance of traditional therapies including the use of nutrients and balanced food increasing the general immunity of the body becomes one of the best options for combating the severe effects of SARSCoV-2 (Wu et al., 2019; Caccialanza et al., 2020; Galanakis, 2020; Jaggers et al., 2020; Panyod et al., 2020; Romano et al., 2020). Malnutrition in general increases the morbidity and mortality of any disease (Curtis et al., 2017). The importance of optimal nutritional status to protect against viral infection and to reduce the effect of coronavirus on lungs has already been studied (Calder et al., 2020). Nutrition therapy had been used as a rehabilitation program for treating specific pandemics, like influenza which had been made fundamental for SARS-CoV-2 infection also. The energy expenditure by the enriched immune cells regularly demands energy to respond to and resolve the underlying infection; hence regular supplementation of optimal nutrients through the exogenous source (diet) will have the best immunological outcomes (Childs et al., 2019).

Nutritious and balanced food items, nutraceuticals, phytochemicals, traditional herbal medicines, Ayurvedic products, probiotics, microelements such as selenium, zinc, copper, magnesium, and vitamins (A, C, E, B6 and B12) help in boosting body's immunity to safeguard against COVID-19, and other viral diseases (Mahima et al., 2013; Rahal et al., 2014; Dhama et al., 2018a; Car, 2020; Chen et al., 2020c; Galanakis, 2020; Gangal et al., 2020; Infusino et al., 2020; Jayawardena et al., 2020; Jahan \& Onay, 2020; Messina et al., 2020; Morais et al., 2020; Panyod et al., 2020; Prasad et al. 2020; Rastogi et al., 2020; Read et al., 2019; Vellingiri et al., 2020). The vitamins such as A, B, C, D and E have been found essential for 
various biological functions, improve immunity and are beneficial in COVID-19 (Beigmohammadi et al., 2020; Xu et al., 2020). Vitamin A has been involved in the enhancement of the adaptive immune responses, and vitamin $\mathrm{C}$ possesses antiviral and anti-inflammatory activities, especially in alveolar epithelial cells and possess ameliorative role in respiratory infection including SARS-CoV-2 (Mawson, 2013; Kim et al., 2013; Baladia et al., 2020; Schloss et al., 2020). Supplementation of Vitamin D has been found to decrease risk of influenza and COVID-19 as well as help in reducing associated mortality (Grant et al., 2020). Vitamin E is a potent antioxidant modulates both humoral and cellular immunity (Fiorino et al., 2017). Similarly, the new interest has been raised against vitamin D sufficiency, deficiency and inadequacy in the SARS-CoV2-infected individuals, since vitamin $\mathrm{D}$ is being involved in the pathways of immune response and hence it has been suspected in lowering the risk of infection by reducing the viral replication rate (Manson \& Bussuk, 2020). Vitamin D inadequacy was correlated with upper and lower respiratory infections (Jaggers et al., 2020). Supplementation of Zinc has shown promising ameliorative effects in SARS-CoV-2 infection / COVID-19 patients (Brewer et al., 2020). Regular nutritional screening based on the Global Leadership Initiative on Malnutrition (GLIM) may help in short term recovery and sustain the immune defences (Thibault et al., 2020).

Omega-3 PUFAs, including protectin D1 could be considered as a potential antiviral drug for the treatment of ARDS and possibly COVID-19 patients (García et al., 2015). The $\omega-3$ PUFAs are metabolized into resolvins and protectin, which have antiinflammatory properties, can reduce NF- $\mathrm{kB}$ activation and COX-2 production, and minimize the activation of ERK1/2 MAPK pathway, all leading to reduction in inflammation (García et al., 2015; Dushianthan et al., 2019). Consumption of increased levels of saturated fatty acids, reduced levels of fiber, sugars, refined carbohydrates and antioxidants in the diet might lead to a higher risk of SARS-CoV-2 infection and its co-morbidities (Butler \& Barrioentos, 2020).

The severely affected SARS-CoV-2 infection patients must be provided with artificial nutrition, either through enteral (EN) or parenteral (PN) approach to satisfy the nutrient demand (Ferrara et al., 2020). It is recommended to supply $84-126 \mathrm{~kJ} / \mathrm{kg} /$ day of energy along with the protein supplementation as the protein reduces catabolism mediated by inflammatory mediators. The amino acid and probiotics supplementation had led to the short term recovery rate by inhibiting the inflammatory responses (Romano et al., 2020).

Apart from dietary nutritious food intake, incorporating healthrelated exercises and yoga in daily routine life aid in optimum biological functions and enhance the performance of immune system to fight viral pathogens including SARS-CoV-2 (Dhama et al., 2015; Tiwari et al., 2018; Golonka et al., 2020; Gupta, 2020; Vellingiri et al., 2020; Zhong et al., 2020b).

\section{Socio-Economic impacts of COVID-19}

The COVID-19 pandemic has posed a huge global burden in terms of its severe public health impacts, panic, socio-economic consequences and millions of people suffering forced locked down in their homes (Ahmad et al., 2020a; Ayittey et al., 2020; Keni et al., 2020; Nicola et al., 2020; Lenzen et al., 2020; Yamin, 2020). As per estimates in India, there is a loss of 10 lakh crore rupees and about 14 crore people have lost jobs (https://en.wikipedia.org/wiki/Economic_ impact_of_the_COVID19_pandemic_in_India; Das 2020). The severity of SARS-CoV-2 increases in patients having diabetes, hypertension and cardiovascular disease, which may have more impacts in resource poor settings. For example, in the US, the racial and ethnic minorities have low socio-economic status, will have high comorbidities, limited access to healthcare, and will have increased vulnerability for SARS-CoV-2 and poor recovery rate (Myers, 2020).

More and more testing for SARS-CoV-2 and strengthening of health care infrastructure facilities could aid in lowering the mortality rates associated with COVID-19. Apart from this follow up of appropriate social distancing; personal biosafety procedures of washing hands frequently with soap, water and applying hand sanitizers; avoiding mass gatherings and unnecessary travels, wearing masks, face shields; adopting recommended quarantine and isolation; biosecurity practices and timely lockdown policies along with other prevention and control strategies would help in containing this virus to some extent until effective vaccines and treatments options are available (Ahmad et al., 2020b; Chu et al. 2020; Dhama et al., 2020a). Ongoing clinical trials of vaccines if it would be successful then could pave ways to bring back the life to normal activities of mass population worldwide. Researchers are striding with high efforts to develop potent COVID-19 vaccines, drugs/medicines and therapies, and until these come in the market till then strict disease prevention and control measures and mitigation strategies including one health approach need to be adopted to contain COVID-19 (Ahmad et al., 2020b; Barbuddhe et al., 2020; Bonilla-Aldana et al., 2020; Ciotti, 2020; Dhama et al., 2020a; Malik et al., 2020b; Rodriguez-Morales et al., 2020b).

Recent advancements in immunology, biotechnology, pharmacology, nanotechnology, nutrition and other progressive fields are needed to be explored fully for designing and developing potent antiviral drugs, vaccines, immunomodulators, medicines and nutritional therapy countering SARS-CoV-2 and halt its spread (Dhama et al., 2013c; Dhama et al., 2014; Dhama et al., 2015; Dhama et al., 2020a; Abd El-Hack et al., 2017; Prasad et al., 2018; Ciotti, 2020; Felsenstein et al., 2020; Keni et al., 2020; Messina et al., 2020; Panyod et al., 2020; Shi et al., 2020b; Vellingiri et al., 2020). 


\section{Conclusion and Future Prospects}

This review summarizes the current knowledge and advancements on SARS-CoV-2 / COVID-19, the basic biology of the virus and the clinical disease, associated risk factors, diagnosis, and potential prophylactic and therapeutic options. The outbreak of COVID-19 from China had affected almost all the countries and territories around the world within a short time of eight months while infecting a few millions and killing nearly one million people. Morbidity and mortality are still on rise. Nature of virus, disease and its epidemiology, pathogenesis, and clinical manifestations are being elucidated from the daily cases and laboratory researches. For the development of potent vaccines and therapeutics, focused research is being carried out that would help in effective disease prevention and control. Understanding of various aspects of COVID-19, including virus, structural biology, clinical manifestations, immunology, risk factors, transmission, diagnosis, treatment and management, can lead to the early development of prophylactic and therapeutic strategies. Considering the crossspecies jumping, spillover events and zoonotic concerns being implicated with origin of SARS-CoV-2 and also the presence of virus detected in few animal species, surveillance and monitoring of animals along with implementing appropriate one health approach need to be reinforced.

Scientists all over the world are engaged in characterizing the SARS-Co-V 2 virus and studying on its various aspects. Researchers are assertive on the effective vaccine and drug development against SARS-CoV-2 and manage the pandemic COVID-19, few of these have reached to different stages of clinical trials. Besides, follow-ups of timely and rapid diagnosis, contact tracing, strengthening of medical facilities, isolation and quarantine, strict prevention and control measures, biosecurity and biosafety procedures, mitigation strategies, and necessary clinical management and treatment of COVID-19 patients including supportive therapies as per available guidelines and research advancements are very crucial to limit the ongoing pandemic. Strategies to enhance immunity through the dietary intake of various healthy and balanced food items, nutraceuticals and the role of nutritional therapy are being exploited and promoted to avoid SARS-CoV-2 infection and lessen the COVID-19 outcome for safeguarding the health of humans. Elderly people and those suffering from pre-existing illnesses and co-morbidities like heart disease, diabetes, hypertension and other diseases require special care and attention during this pandemic as the severity of COVID-19 increases in such cases. We need to plan sound strategies for the future with regards to preparedness to face challenges of highly infectious pathogens such as SARS-CoV-2 posing high risks for the survival of mankind, and hopefully, the current ongoing COVID-19 pandemic has taught us much and to believe that prevention is always better than cure.

\section{Author contributions}

All the authors substantially contributed to the conception, compilation of data, checking and approving the final version of the manuscript, and agree to be accountable for its contents.

\section{Acknowledgments}

All the authors acknowledge and thank their respective Institutes and Universities.

\section{Funding}

This compilation is a review article written by its authors and required no substantial funding to be stated.

\section{Conflict of Interest}

There exist no commercial or financial relationships that could, in any way, lead to a potential conflict of interest.

\section{References}

Abbatecola AM, Antonelli-Incalzi R (2020) Editorial: COVID-19 Spiraling of Frailty in Older Italian Patients. Journal of Nutrition Health \& Aging 24(5):453-455.

Abbott TR, Dhamdhere G, Liu Y, Lin X, Goudy L, Zeng L, Chemparathy A, Chmura S, Heaton NS, Debs R, Pande T, Endy D, La Russa MF, Lewis DB, Qi LS (2020) Development of CRISPR as an Antiviral Strategy to Combat SARS-CoV-2 and Influenza. Cell 181(4):865-876.e12. doi: 10.1016/j.cell.2020.04.020.

Abd El-Hack ME, Alagawany M, Farag MR, Arif M, Emam M, Dhama K, Sarwar M, Sayab M (2017) Nutritional and pharmaceutical applications of nanotechnology: Trends and advances. International Journal of Pharmacology 13(4): 340-350.

Adamo M, Lombardi CM, Metra M (2020) June 2020 at a glance: focus on COVID-19, quality of life and comorbidities. European Journal of Heart Failure 22(6):917-918. doi: 10.1002/ejhf.1515.

Aftab SO, Ghouri MZ, Masood MU, Haider Z, Khan Z, Ahmad A, Munawar N (2020) Analysis of SARS-CoV-2 RNA-dependent RNA polymerase as a potential therapeutic drug target using a computational approach. Journal of Translational Medicine 18(1):275. doi: 10.1186/s12967-020-02439-0.

Afzal A (2020) Molecular diagnostic technologies for COVID-19: Limitations and challenges Journal of Advanced Research 10.1016/j.jare.2020.08.002. doi:10.1016/j.jare.2020.08.002

Agrawal A, Singh SG (2020) PREFACE on the Special Issue 'Technologies for Fighting COVID-19'. Transactions of the Indian National Academy of Engineering 1-5. doi: 10.1007/s41403-020-00156-0. 
Ahmad T, Haroon, Baig M, Hui J (2020a) Coronavirus disease 2019 (COVID-19) pandemic and economic impact. Pakistan Journal of Medical Sciences 36 (COVID19-S4): S73-S78.

Ahmad T, Haroon, Dhama K, Sharun K, Khan FM, Ahmed I, Tiwari R, Musa TH, Khan M, Bonilla-Aldana DK, J Rodriguez-Morales A, Hui J (2020b) Biosafety and biosecurity approaches to restrain/contain and counter SARS-CoV-2/COVID-19 pandemic: a rapid-review. Turkiah Journal of Biology 44(3): 132-145.

Ahuja AS, Reddy VP, Marques O (2020) Artificial intelligence and COVID-19: A multidisciplinary approach. Integrative Medicine Research 9(3):100434. doi:10.1016/j.imr.2020.100434

Ai JW, Zhang Y, Zhang HC, Xu T, Zhang WH (2020) Era of molecular diagnosis for pathogen identification of unexplained pneumonia, lessons to be learned. Emerging Microbes \& Infections 9(1):597-600.

Alijotas-Reig J, Esteve-Valverde E, Belizna C, Selva-O'Callaghan A, Pardos-Gea J, Quintana A, Mekinian A, Anunciacion-Llunell A, Miró-Mur F (2020) Immunomodulatory therapy for the management of severe COVID-19. Beyond the anti-viral therapy: A comprehensive review. Autoimmunity Reviews 19(7):102569. doi: 10.1016/j.autrev.2020.102569.

Almeida JD, Berry DM, Cunningham CH, Hamre D, Hofstad MS Mallucci L, McIntosh K, Tyrrell DAJ (1968) Virology: coronaviruses. Nature 220:650.

Apicella M, Campopiano MC, Mantuano M, Mazoni L, Coppelli A, Del Prato S (2020) COVID-19 in people with diabetes: understanding the reasons for worse outcomes. Lancet Diabetes \& Endocrinology S2213-8587(20)30238-2. doi:10.1016/S22138587(20)30238-2

Arab-Mazar Z, Sah R, Rabaan AA, Dhama K, Rodriguez-Morales AJ (2020) Mapping the incidence of the COVID-19 hotspot in Iran Implications for Travellers. Travel Medicine and Infectious Disease 2020: 101630.

Arumugam VA, Thangavelu S, Fathah Z, et al. (2020) COVID-19 and the World with Co-Morbidities of Heart Disease, Hypertension and Diabetes. Journal of Pure and Applied Microbiology 14(3):16231638. doi: 10.22207/JPAM.14.3.01.

Asai A, Konno M, Ozaki M, Otsuka C, Vecchione A, Arai T, Kitagawa T, Ofusa K, Yabumoto M, Hirotsu T, Taniguchi M, Eguchi H, Doki Y, Ishii H (2020) COVID-19 Drug discovery using intensive approaches. International Journal of Molecular Sciences 21(8):2839. doi: 10.3390/ijms21082839.

Astuti I, Ysrafil (2020) Severe Acute Respiratory Syndrome Coronavirus 2 (SARS-CoV-2): An overview of viral structure and host response. Diabetes \& Metabolic Syndrome 14(4):407-412.
Ayittey FK, Ayittey MK, Chiwero NB, Kamasah JS, Dzuvor C (2020) Economic Impacts of Wuhan 2019-nCoV on China and the World. Journal of Medical Virology 92(5): 473-475.

Baladia E, Pizarro AB, Ortiz-Muñoz L, Rada G (2020) Vitamin C for COVID-19: A living systematic review. Medwave 20(6):e7978. doi: 10.5867/medwave.2020.06.7978.

Baradaran A, Ebrahimzadeh MH, Baradaran A, Kachooei AR (2020) Prevalence of Comorbidities in COVID-19 Patients: A Systematic Review and Meta-Analysis. Archives of Bone and Joint Surgery 8 (Suppl 1) : 247-255. doi:10.22038/abjs.2020.47754.2346

Barbuddhe SB, Rawool DB, Gaonkar PP, Vergis J, Dhama K, Malik SS (2020) Global scenario, public health concerns and mitigation strategies to counter current ongoing SARS-CoV-2 / COVID-19 pandemic. Human Vaccines and Immunotherapeutics 16(12): doi: $10.1080 / 21645515.2020 .1810496$.

Baron SA, Devaux C, Colson P, Raoult D, Rolain JM (2020) Teicoplanin: an alternative drug for the treatment of coronavirus COVID-19? International Journal of Antimicrobial Agents 55(4): 105944.

Beigmohammadi MT, Bitarafan S, Hoseindokht A, Abdollahi A, Amoozadeh L, Mahmoodi Ali Abadi M, Foroumandi M (2020) Impact of vitamins $\mathrm{A}, \mathrm{B}, \mathrm{C}, \mathrm{D}$, and $\mathrm{E}$ supplementation on improvement and mortality rate in ICU patients with coronavirus-19: a structured summary of a study protocol for a randomized controlled trial. Trials 21(1):614. doi: 10.1186/s13063-020-04547-0.

Ben-Ami R, Klochendler A, Seidel M, Sido T, Gurel-Gurevich O, Yassour M, Meshorer E, Benedek G, Fogel I, Oiknine-Djian E, Gertler A, Rotstein Z, Lavi B, Dor Y, Wolf DG, Salton M, Drier Y (2020) Hebrew University-Hadassah COVID-19 Diagnosis Team. Large-scale implementation of pooled RNA extraction and RT-PCR for SARS-CoV-2 detection. Clinical Microbiology and Infection 26(9):1248-53. doi: 10.1016/j.cmi.2020.06.009.

Bhatia R (2020) Need for integrated surveillance at human-animal interface for rapid detection \& response to emerging coronavirus infections using One Health approach. Indian Journal of Medical Research 151:132-5.

Bonato G, Dioscoridi L, Mutignani M (2020) Faecal-oral transmission of SARS-COV-2: practical implications. Gastroenterology S0016-5085(20): 30449-2.

Bonilla-Aldana DK, Dhama K, Rodriguez-Morales AJ (2020) Revisiting the One Health Approach in the Context of COVID-19: A look into the Ecology of this Emerging Disease. Advances in Animal and Veterinary Sciences 8(3):234-237.

Bornstein SR, Dalan R, Hopkins D, Mingrone G and Boehm BO (2020) Endocrine and metabolic link to coronavirus infection. Nature Reviews Endocrinology 16:297-298. 
Brake SJ, Barnsley K, Lu W, McAlinden KD, Eapen MS, Sohal SS (2020) Smoking upregulates angiotensin-converting enzyme-2 receptor: a potential adhesion site for novel coronavirus SARS-CoV2 (Covid-19). Journal of Clinical Medicine 9(3): 841 https://doi.org/10.3390/jcm9030841.

Brewer J, Gomez Marti JL, Brufsky A (2020) Potential interventions for SARS-CoV-2 infections: Zinc showing promise. Journal of Medical Virology doi: 10.1002/jmv.26523.

Broughton JP, Deng X, Yu G, Fasching CL, Servellita V, Singh J, Miao X, Streithorst JA, Granados A, Sotomayor-Gonzalez A, Zorn K, Gopez A, Hsu E, Gu W, Miller S, Pan CY, Guevara H, Wadford DA, Chen JS, Chiu CY (2020) CRISPR-Cas12-based detection of SARS-CoV-2. Nature Biotechnology 38(7):870-874.

Butler MJ, Barrientos RM (2020) The impact of nutrition on COVID-19 susceptibility and long-term consequences. Brain Behaviour and Immunity 87: 53-54.

Caccialanza R, Laviano A, Lobascio F, Montagna E, Bruno R, Ludovisi S, Corsico AG, Di Sabatino A, Belliato M, Calvi M, Iacona I, Grugnetti G, Bonadeo E, Muzzi A, Cereda E (2020) Early nutritional supplementation in non-critically ill patients hospitalized for the 2019 novel coronavirus disease (COVID-19): Rationale and feasibility of a shared pragmatic protocol. Nutrition 74:110835.

Calder PC, Carr AC, Gombart AF, Eggersdorfer M (2020) Optimal Nutritional Status for a Well-Functioning Immune System Is an Important Factor to Protect against Viral Infections. Nutrients 12(4):1181. doi: 10.3390/nu12041181.

Caly L, Druce JD, Catton MG, Jans DA, Wagstaff KM (2020) The FDA-approved drug ivermectin inhibits the replication of SARSCoV-2 in vitro. Antiviral Research 178:104787.

Capell T, Twyman RM, Armario-Najera V, Ma JK, Schillberg S, Christou P (2020) Potential Applications of Plant Biotechnology against SARS-CoV-2. Trends in Plant Science S13601385(20)30124-2.

Carr AC (2020) A new clinical trial to test high-dose vitamin C in patients with COVID-19. Version 2. Critical Care 24(1):133.

Carter LJ, Garner LV, Smoot JW, Li Y, Zhou Q, Saveson CJ, Sasso JM, Gregg AC, Soares DJ, Beskid TR, Jervey SR, Liu C (2020) Assay techniques and test development for COVID-19 diagnosis. ACS Central Science 6(5):591-605. doi: 10.1021/acscentsci.0c00501.

Casadevall A, Pirofski LA (2020) The convalescent sera option for containing COVID-19. Journal of Clinical Investigation 4: 15451548. https://doi.org/10.1172/JCI138003.

Case JB, Ashbrook AW, Dermody TS, Denison MR (2016) Mutagenesis of $S$-adenosyl-L-methionine-binding residues in coronavirus nsp14 N7-methyltransferase demonstrates differing requirements for genome translation and resistance to innate immunity. Journal of Virology 90:7248-7256.

CDC (2020) Assessing Risk Factors for Severe COVID-19 Illness. https://www.cdc.gov/coronavirus/2019-ncov/covid-

data/investigations-discovery/ assessing-risk-factors.html. Accessed on 13th July 2020.

Chan JF, Kok KH, Zhu Z, Chu H, To KK, Yuan S, Yuen KY (2020) Genomic characterization of the 2019 novel human-pathogenic coronavirus isolated from a patient with atypical pneumonia after visiting Wuhan. Emerging Microbes \& Infections 9(1):221-236. doi: 10.1080/22221751.2020.1719902. Erratum in: Emerging Microbes \& Infections 9(1):540.

Chen L, Hu C, Hood M, Zhang X, Zhang L, Kan J, Du J (2020c) A Novel Combination of Vitamin C, Curcumin and Glycyrrhizic Acid Potentially Regulates Immune and Inflammatory Response Associated with Coronavirus Infections: A Perspective from System Biology Analysis. Nutrients 12(4):1193.

Chen L, Xiong J, Bao L, Shi Y (2020b) Convalescent plasma as a potential therapy for COVID-19. Lancet Infectious Disease 20(4):398-400. doi: 10.1016/S1473-3099(20)30141-9.

Chen X, Hu W, Ling J, Mo P, Zhang Y, Jiang Q, Ma Z, Cao Q, Deng L, Song S Zheng R, Gao S, Ke H, Gui X, Lundkvist Å, Li J, Lindahl JF, Xiong Y (2020a) Hypertension and Diabetes Delay the Viral Clearance in COVID-19 Patients. medRxiv 2020.2003.2022.20040774.

Cheng MP, Papenburg J, Desjardins M, Kanjilal S, Quach C, Libman M, Dittrich S, Yansouni CP (2020) Diagnostic Testing for Severe Acute Respiratory Syndrome-Related Coronavirus-2: A Narrative Review. Annals of Internal Medicine M20-1301.

Childs CE, Calder P and Miles EA (2019) Diet and immune function. Nutrients 11:1993.

Chou R, Dana T, Buckley DI, Selph S, Fu R, Totten AM (2020) Epidemiology of and Risk Factors for Coronavirus Infection in Health Care Workers. Annals of Internal Medicine M20-1632.

Chu DK, Akl EA, Duda S, Solo K, Yaacoub S, Schünemann HJ, Elharakeh A, Bognanni A, Lotfi T, Loeb M, Hajizadeh A (2020). Physical distancing, face masks, and eye protection to prevent person-to-person transmission of SARS-CoV-2 and COVID-19: a systematic review and meta-analysis. The Lancet 395(10242): P1973-1987, doi.org/10.1016/S0140-6736(20)31142-9

Ciotti M, Ciccozzi M, Terrinoni A, Jiang WC, Wang CB, Bernardini S (2020) The COVID-19 pandemic. Critical Reviews in Clinical Labortatory Sciences 57(6):365-388. 
Combating COVID-19: NIV-Pune Develops India's First Antibody Testing Kit -ELISA, Health News, ET HealthWorld (2020) (accessed May 28, 2020), https://health .economictimes.indiatimes.com/news/diagnostics/combating-covid-19niv-punedevelops-indias-first-antibody-testing-kit-elisa/75666103.

Cornillez-Ty CT, Liao L, Yates JR, Kuhn P, Buchmeier MJ (2009) Severe acute respiratory syndrome coronavirus nonstructural protein 2 interacts with a host protein complex involved in mitochondrial biogenesis and intracellular signaling. Journal of Virology 83:10314-10318.

Cottam EM, Whelband MC, Wileman T (2014) Coronavirus NSP6 restricts autophagosome expansion. Autophagy 10:1426-1441.

Cunningham AC, Goh HP, Koh D (2020) Treatment of COVID-19: old tricks for new challenges. BioMed Central (BMC) 24:91.

Curtis LJ, Bernier P, Jeejeebhoy K, Allard J, Duerksen D, Gramlich L, Laporte M, Keller HH (2017) Costs of hospital malnutrition. Clinical Nutrition 36(5):1391-1396. doi: 10.1016/j.clnu.2016.09.009.

Das G (2020) 136 million jobs at risk in post-corona India. Livemint. Retrieved 2 April 2020.

Dawood AA (2020) Mutated COVID-19, May Foretells Mankind in a Great Risk in the Future. New Microbes and New Infections 35:100673.

Decroly E, Debarnot C, Ferron F, Bouvet M, Coutard B, Imbert I, Gluais L, Papageorgiou N, Sharff A, Bricogne G, Ortiz-Lombardia M, Lescar J, Canard B (2011) Crystal structure and functional analysis of the sars-coronavirus RNA cap 2'-O-methyltransferase nsp10/nsp16 complex. PLoS Pathogens 7:e1002059.

Devaux CA, Rolain JM, Colson P, Raoult D (2020) New insights on the antiviral effects of chloroquine against coronavirus: what to expect for COVID-19? International Journal of Antimicrobial Agents 55(5):105938. doi: 10.1016/j.ijantimicag.2020.105938.

Dhama K, Chakraborty S, Tiwari R, Verma AK, Saminathan M, et al. (2014) A concept paper on novel technologies boosting production and safeguarding health of humans and animals. Research Opinions in Animal and Veterinary Sciences 4(7): 353370.

Dhama K, Chakraborty S, Wani MY, Tiwari R and Barathidasan R (2013c). Cytokine therapy for combating animal and human diseases - A review. Research Opinions in Animal and Veterinary Sciences 3(7): 195-208

Dhama K, Karthik K, Khandia R, Chakraborty S, Munjal A, Latheef SK, Kumar D, Ramakrishnan MA, Malik YS, Singh R, Malik SVS, Singh RK, Chaicumpa W (2018b) Advances in Designing and
Developing Vaccines, Drugs, and Therapies to Counter Ebola Virus. Frontiers in Immunology 9: 1803.

Dhama K, Karthik K, Khandia R, Munjal A, Tiwari R, Rana R, Khurana SK, Sana Ullah, Khan RU, Alagawany M, Farag MR, Dadar M, Joshi SK (2018a) Medicinal and therapeutic potential of herbs and plant metabolites / extracts countering viral pathogens Current knowledge and future prospects. Current Drug Metabolism 19(3):236-263.

Dhama K, Khan S, Tiwari R, Sircar S, Bhat S, Malik YS, Singh KP, Chaicumpa W, Bonilla-Aldana DK, Rodriguez-Morales AJ (2020a) Coronavirus Disease 2019-COVID-19. Clinical Microbiology Reviews 33(4):e00028-20.

Dhama K, Saminathan M, Jacob SS, Singh M, Karthik K, Amarpal, Tiwari R, Sunkara LT, Malik YS, Singh RK (2015) Effect of immunomodulation and immunomodulatory agents on health with some bioactive principles, modes of action and potent biomedical applications. International Journal of Pharmacology 11(4): 253-290.

Dhama K, Patel SK, Kumar R, Rana J, Yatoo MI, Kumar A, Tiwari R, Dhama J, Natesan S, Rajendra Singh and Harapan H (2020c) Geriatric population during the COVID-19 pandemic: problems, considerations, exigencies, and beyond. Frontiers in Public Health (In Press).

Dhama K, Patel SK, Pathak M, Yatoo MI, Tiwari R, Malik YS, Singh R, Sah R, Rabaan AA, Bonilla-Aldana DK, RodriguezMorales AJ (2020b) An update on SARS-CoV-2/COVID-19 with particular reference to its clinical pathology, pathogenesis, immunopathology and mitigation strategies. Travel Medicine and Infectious Disease 101755.

Dhama K, Patel SK, Sharun K, Pathak M, Tiwari R, Yatoo MI, Malik YS, Sah R, Rabaan AA, Panwar PK, Singh KP, Michalak I, Chaicumpa W, Martinez-Pulgarin DF, Bonilla-Aldana DK, Rodriguez-Morales AJ. (2020d) SARS-CoV-2 jumping the species barrier: zoonotic lessons from SARS, MERS and recent advances to combat this pandemic virus. Travel Medicine and Infectious Disease 101830. doi: 10.1016/j.tmaid.2020.101830.

Dhama K, Sharun K, Tiwari R, Dadar M, Malik YS, Singh KP, Chaicumpa W (2020e) COVID-19, an emerging coronavirus infection: advances and prospects in designing and developing vaccines, immunotherapeutics, and therapeutics. Human Vaccines and Immunotherapeutics 16(6):1232-1238.

Dhama K, Verma AK, Tiwari R, Chakraborty S, Vora K, Kapoor S, Deb R, Karthik K, Singh R, Munir M, Natesan S (2013a) A perspective on applications of geographical information system (GIS); an advanced tracking tool for disease surveillance and monitoring in veterinary epidemiology. Advances in Animal and Veterinary Sciences 1(1): 14-24. 
Dhama K, Wani MY, Deb R., Karthik K, Tiwari R, Barathidasan R, Kumar A, Mahima, Verma AK, Singh SD (2013b) Plant based oral vaccines for human and animal pathogens - a new era of prophylaxis: Current and future perspectives. Journal of Experimental Biology and Agricultural Sciences 1(1): 1-12.

Ding S, Liang TJ (2020) Is SARS-CoV-2 also an enteric pathogen with potential fecal-oral transmission: A COVID-19 virological and clinical review. Gastroenterology S0016-5085(20)30571-0.

Dinnes J, Deeks JJ, Adriano A, Berhane S, Davenport C, Dittrich S, Emperador D, Takwoingi Y, Cunningham J, Beese S, Dretzke J, Ferrante di Ruffano L, Harris IM, Price MJ, Taylor-Phillips S, Hooft L, Leeflang MM, Spijker R, Van den Bruel A (2020) Cochrane COVID-19 Diagnostic Test Accuracy Group. Rapid, point-of-care antigen and molecular-based tests for diagnosis of SARS-CoV-2 infection. Cochrane Database of Systematic Reviews 8:CD013705. doi: 10.1002/14651858.CD013705.

Dodds WJ (2020) Coronavirus SARS-CoV-2 (COVID-19) and Companion Animal Pets. Journal of Immunology and Allergy 1(2):1-3. DOI: Mapsci-JIA-1(2)-010

Dong E, Du H, Gardner L (2020) An interactive web-based dashboard to track COVID-19 in real time. Lancet Infectious Diseases S1473-3099(20): 30120-1.

Dushianthan A, Cusack R, Burgess VA, Grocott MP, Calder PC (2019) Immunonutrition for acute respiratory distress syndrome (ARDS) in adults. Cochrane Database of Systematic Reviews 1(1):CD012041. doi: 10.1002/14651858.CD012041.pub2.

Dyal JW, Grant MP, Broadwater K, Bjork A, Waltenburg MA, Gibbins JD, Hale C, Silver M, Fischer M, Steinberg J, Basler CA, Jacobs JR, Kennedy ED, Tomasi S, Trout D, Hornsby-Myers J, Oussayef NL, Delaney LJ, Patel K, Shetty V, Kline KE, Schroeder B, Herlihy RK, House J, Jervis R, Clayton JL, Ortbahn D, Austin C, Berl E, Moore Z, Buss BF, Stover D, Westergaard R, Pray I, DeBolt M, Person A, Gabel J, Kittle TS, Hendren P, Rhea C, Holsinger C, Dunn J, Turabelidze G, Ahmed FS, deFijter S, Pedati CS, Rattay K, Smith EE, Luna-Pinto C, Cooley LA, Saydah S, Preacely ND, Maddox RA, Lundeen E, Goodwin B, Karpathy SE, Griffing S, Jenkins MM, Lowry G, Schwarz RD, Yoder J, Peacock G, Walke HT, Rose DA, Honein MA (2020) COVID-19 Among Workers in Meat and Poultry Processing Facilities - 19 States, April 2020. Morbidity and Mortality Weekly Report 69:18.

FAO (2020a) Mitigating the impacts of COVID-19 on the livestock sector. Rome https://doi.org/10.4060/ca8799en

FAO (2020b) Guidelines to mitigate the impact of COVID-19 pandemic on livestock production and animal health. Rome. https://doi.org/10.4060/ca9177en
Farfan MJ, Torres JP, O'Ryan M, Olivares M, Gallardo P, Lastra J, Salas C. (2020). Optimizing RT-PCR detection of SARS-CoV-2 for developing countries using pool testing. Revista Chilena de Infectologia : organo oficial de la Sociedad Chilena de Infectologia 37(3):276-280. doi: 10.4067/s0716-10182020000300276.

FDA (2020) EUA Authorized Serology Test Performance. https://www.fda.gov/medical-devices/emergency-situations-medicaldevices/eua-authorized-serology-test-performance. Accessed 13th July 2020.

Felsenstein S, Herbert JA, McNamara PS, Hedrich CM (2020) COVID-19: Immunology and treatment options. Clinical Immunology 215:108448. doi:10.1016/j.clim.2020.108448

Ferrara F, Rosa FD, Vitiello A (2020) The Central Role of Clinical Nutrition in COVID-19 Patients During and After Hospitalization in Intensive Care Unit. SN Comprehensive Clinical Medicine 38 (1): 1- 484 .

Fiorino S, Bacchi-Reggiani ML, Leandri P, Loggi E, Andreone P (2017) Vitamin $E$ for the treatment of children with hepatitis B e antigen-positive chronic hepatitis: A systematic review and metaanalysis. World Journal of Hepatology 9(6):333-342. doi: 10.4254/wjh.v9.i6.333.

Gabarre P, Dumas G, Dupont T, Darmon M, Azoulay E, Zafrani L (2020) Acute kidney injury in critically ill patients with COVID-19. Intensive Care Medicine doi: 10.1007/s00134-020-06153-9.

Galanakis CM (2020) The Food Systems in the Era of the Coronavirus (COVID-19) Pandemic Crisis. Foods 4: 523. https://doi.org/10.3390/foods9040523.

Gandhi P, Bafna R, Arabale G Engineer S, Phadke S (2020) Olfactory device for large scale pre-screening for COVID-19. Transactions of the Indian National Academy of Engineering 1-4. https ://doi.org/10.1007/s4140 3-020-00126 -6.

Gangal N, Nagle V, Pawar Y, Dasgupta S (2020) Reconsidering Traditional Medicinal Plants to Combat COVID-19. AIJR Preprints https://preprints.aijr.org/index.php/ap/preprint/view/34

Gao Y, Yan L, Huang Y, Liu F, Zhao Y, Cao L, Wang T, Sun Q, Ming Z, Zhang L, Ge J, Zheng L, Zhang Y, Wang H, Zhu Y, Zhu C, Hu T, Hua T, Zhang B, Yang X, Li J, Yang H, Liu Z, Xu W, Guddat LW, Wang Q, Lou Z, Rao Z (2020) Structure of the RNA-dependent RNA polymerase from COVID-19 virus. Science. https://doi.org/10.1126/science.abb7498.

García de Acilu M, Leal S, Caralt B, Roca O, Sabater J, Masclans JR (2015) The Role of Omega-3 Polyunsaturated Fatty Acids in the Treatment of Patients with Acute Respiratory Distress Syndrome: A 
Clinical Review. Biomed Research International 2015:653750. doi: 10.1155/2015/653750.

Geleris J, Sun Y, Platt J, Zucker J, Baldwin M, Hripcsak G, Labella A, Manson DK, Kubin C, Barr RG, Sobieszczyk ME, Schluger NW (2020) Observational Study of Hydroxychloroquine in Hospitalized Patients with Covid-19. New England Journal of Medicine 382(25):2411-2418. doi: 10.1056/NEJMoa2012410.

Gollakner R, Capua I (2020) Is COVID-19 the first pandemic that evolves into a panzootic?. Veterinaria Italiana 56(1):7-8.

Golonka RM, Saha P, Yeoh BS, Chattopadhyay S, Gewirtz AT, Joe B, Vijay-Kumar M. (2020) Harnessing innate immunity to eliminate SARS-CoV-2 and ameliorate COVID-19 disease. Physiological Genomics 52(5):217-221. doi: 10.1152/physiolgenomics.00033.2020.

Grant WB, Lahore H, McDonnell SL, Baggerly CA, French CB, Aliano JL, Bhattoa HP (2020) Evidence that Vitamin D Supplementation Could Reduce Risk of Influenza and COVID-19 Infections and Deaths. Nutrients 12(4):988. doi: 10.3390/nu12040988.

Guan WJ, Chen RC, Zhong NS (2020) Strategies for the prevention and management of coronavirus disease 2019. European Respiratory Journal 55(4):2000597. doi:10.1183/13993003.00597-2020

Guo YR, Cao QD, Hong ZS, Tan YY, Chen SD, Jin HJ, Tan KS, Wang DY, Yan Y (2020) The origin, transmission and clinical therapies on coronavirus disease 2019 (COVID-19) outbreak - an update on the status. Military Medical Research 7(1):11. doi: 10.1186/s40779-020-00240-0.

Gupta A (2020) Is Immuno-modulation the Key to COVID-19 Pandemic?. Indian Journal of Orthopaedics 27: 1-4.

Hackbart M, Deng X, Baker SC (2020) Coronavirus endoribonuclease targets viral polyuridine sequences to evade activating host sensors. Proceedings of the National Academy of Sciences USA 117:8094-8103.

Hart OE, Halden RU (2020) Computational analysis of SARS-CoV2/COVID-19 surveillance by wastewater-based epidemiology locally and globally: Feasibility, economy, opportunities and challenges. Science of the Total Environment 730:138875.

Henry BM, Lippi G. (2020) Chronic kidney disease is associated with severe coronavirus disease 2019 (COVID-19) infection. International Urolology and Nephrology 52(6):1193-1194. doi: 10.1007/s11255-020-02451-9.

Hindson J (2020) COVID-19: faecal-oral transmission?. Nature Reviews Gastroenterology \& Hepatology 17(5):259. doi:10.1038/s41575-020-0295-7.
Hinton DM (2020) Emergency Use Authorization for qSARS-CoV-2 IgG/IgM Rapid Test (Cellex Inc.). U.S. Food \& Drug Administration $1-8$.

Hobbs EC, Reid TJ (2020) Animals and SARS-CoV-2: Species susceptibility and viral transmission in experimental and natural conditions, and the potential implications for community transmission. Transboundary and Emerging Diseases doi: 10.1111/tbed.13885.

Hogue BG, Machamer CE (2008) Coronavirus structural proteins and virus assembly. ASM Press 179-200.

Hou T, Zeng W, Yang M, Chen W, Ren L, Ai J, Wu J, Liao Y, Gou X, Li Y, Wang X, Su H, Gu B, Wang J, Xu T (2020) Development and evaluation of a rapid CRISPR-based diagnostic for COVID-19. PLoS Pathogens 16(8):e1008705. doi: 10.1371/journal.ppat.1008705.

https://www.worldometers.info/coronavirus/. Accessed on $9^{\text {th }}$ November, 2020.

Hu X, Deng Q, Li J, Chen J, Wang Z, Zhang X, Fang Z, Li H, Zhao Y, Yu P, Li W, Wang X, Li S, Zhang L, Hou T (2020) Development and Clinical Application of a Rapid and Sensitive Loop-Mediated Isothermal Amplification Test for SARS-CoV-2 Infection. mSphere 5(4):e00808-20. doi: 10.1128/mSphere.00808-20.

Huang C, Lokugamage KG, Rozovics JM, Narayanan K, Semler BL, Makino S (2011) SARS coronavirus nsp1 protein induces templatedependent endonucleolytic cleavage of mRNAs: viral mRNAs are resistant to nsp1-induced RNA cleavage. PLoS Pathogens 7:e1002433.

Huang WH, Teng LC, Yeh TK, Chen YJ, Lo WJ, Wu MJ, Chin CS, Tsan YT, Lin TC, Chai JW, Lin CF, Tseng CH, Liu CW, Wu CM, Chen PY, Shi ZY, Liu PY (2020) 2019 novel coronavirus disease (COVID-19) in Taiwan: Reports of two cases from Wuhan, China. Journal of Microbiology Immunology and Infection 53(3):481-484. doi: 10.1016/j.jmii.2020.02.009.

ICTV (2020) International Committee on Taxonomy of Viruses. Virus taxonomy 2020 report. Available at: https://talk.ictvonline.org/information/w/news/1300/page

Infusino F, Marazzato M, Mancone M, Fedele F, Mastroianni CM, Severino P, Ceccarelli G, Santinelli L, Cavarretta E, Marullo AGM, Miraldi F, Carnevale R, Nocella C, Biondi-Zoccai G, Pagnini C, Schiavon S, Pugliese F, Frati G, d'Ettorre G (2020) mDiet Supplementation, Probiotics, and Nutraceuticals in SARS-CoV-2 Infection: A Scoping Review. Nutrients 12(6):E1718. doi: 10.3390/nu12061718. 
Jaggers GK, Watkins BA, Rodriguez RL (2020) COVID-19: Repositioning nutrition research for the next pandemic. Nutrition Research doi: 10.1016/j.nutres.2020.07.005

Jahan I, Onay A (2020) Potentials of plant-based substance to inhabit and probable cure for the COVID-19. Turkish Journal of Biology 44(3):228-241.

Jaiswal NK, Saxena SK (2020) Classical coronavirus. In: Coronavirus Disease 2019 (COVID-19). Editor SK Saxena. Book series. Medical Virology: from pathogenesis to disease control. 978987. https://www.springer.com/gp/book/9789811548130

Jang KJ, Jeong S, Kang DY, Sp N, Yang YM, Kim DE (2020) A high ATP concentration enhances the cooperative translocation of the SARS coronavirus helicase nsP13 in the unwinding of duplex RNA. Scientific Reports 10:4481.

Jayawardena R, Sooriyaarachchi P, Chourdakis M, Jeewandara C, Ranasinghe P (2020) Enhancing immunity in viral infections, with special emphasis on COVID-19: A review. Diabetes \& Metabolic Syndrome 14(4):367-382. doi: 10.1016/j.dsx.2020.04.015.

Jhunjhunwala A (2020) Role of telecom network to manage COVID-19 in India: Aarogya setu. Transactions of the Indian National Academy of Engineering 1-5. https ://doi.org/10.1007/s4140 3-020-00109-7

Ji W, Wang W, Zhao X, Zai J, Li X (2020) Cross-species transmission of the newly identified coronavirus 2019-nCoV. Journal of Medical Virology 92(4):433-440.

Jin JM, Bai P, He W, Wu F, Liu XF, Han DM, Liu S, Yang JK (2020) Gender Differences in Patients With COVID-19: Focus on Severity and Mortality. Frontiers in Public Health 8:152.

Jo WK, de Oliveira-Filho EF, Rasche A, Greenwood AD, Osterrieder K, Drexler JF (2020) Potential zoonotic sources of SARS-CoV-2 infections. Transboundary and Emerging Diseases, doi: 10.1111/tbed.13872.

Jordan RE (2020) Covid-19: risk factors for severe disease and death. British Medical Journal(BMJ) 368:m1198.

Kamel Boulos MN, Geraghty EM (2020) Geographical tracking and mapping of coronavirus disease COVID-19/severe acute respiratory syndrome coronavirus 2 (SARS-CoV-2) epidemic and associated events around the world: how 21st century GIS technologies are supporting the global fight against outbreaks and epidemics. International Journal of Health Geographics 19(1): 8. https://doi.org/10.1186/s12942-020-00202-8

Karthik K, Aravindh Babu RP, Dhama K, Chitra MA, Kalaiselvi G, Alagesan Senthilkumar TM, Raj GD (2020) Biosafety Concerns
During the Collection, Transportation, and Processing of COVID-19 Samples for Diagnosis. Archives of Medical Research 51(7):623-30. doi: 10.1016/j.arcmed.2020.08.007.

Keam S, Megawati D, Patel SK, Tiwari R, Dhama K, Harapan H (2020) Immunopathology and immunotherapeutic strategies in severe acute respiratory syndrome coronavirus 2 infection. Reviews in Medical Virology 10.1002/rmv.2123. doi:10.1002/rmv.2123.

Keni R, Alexander A, Nayak PG, Mudgal J, Nandakumar K (2020) COVID-19: Emergence, Spread, Possible Treatments, and Global Burden. Frontiers in Public Health 8: 216.

Khailany RA, Safdar M, Ozaslan M (2020) Genomic characterization of a novel SARS-CoV-2. Gene Reports 19: 100682. doi: 10.1016/j.genrep.2020.100682.

Kim D, Lee JY, Yang JS, Kim JW, Kim VN, Chang H (2020a) The Architecture of SARS-CoV-2 Transcriptome. Cell 181(4):914921.e10.

Kim TK, Lim HR, Byun JS (2020b) Vitamin C supplementation reduces the odds of developing a common cold in Republic of Korea Army recruits: randomised controlled trial. BMJ Mil Health. bmjmilitary-2019-001384. doi: 10.1136/bmjmilitary-2019-001384.

Kim Y, Kim H, Bae S, Choi J, Lim SY, Lee N, Kong JM, Hwang YI, Kang JS, Lee WJ (2013) Vitamin C Is an Essential Factor on the Anti-viral Immune Responses through the Production of Interferon$\alpha / \beta$ at the Initial Stage of Influenza A Virus (H3N2) Infection. Immune Network 13(2):70-4. doi: 10.4110/in.2013.13.2.70.

Konwar AN, Borse V (2020) Current status of point-of-care diagnostic devices in the Indian healthcare system with an update on COVID-19 pandemic. Sensors International. 1:100015. doi: 10.1016/j.sintl.2020.100015.

Kumar GV, Jeyanthi V, Ramakrishnan S (2020) A short review on antibody therapy for COVID-19. New Microbes and New Infections 35. 100682. https://doi.org/10.1016/j.nmni.2020.100682.

La Marca A, Capuzzo M, Paglia T, Roli L, Trenti T, Nelson SM. Testing for SARS-CoV-2 (COVID-19) (2020) a systematic review and clinical guide to molecular and serological in-vitro diagnostic assays .Reproductive Biomedicine Online S1472-6483(20)30318-7. doi: 10.1016/j.rbmo.2020.06.001.

La Rosa G, Bonadonna L, Lucentini L, Kenmoe S, Suffredini E (2020) Coronavirus in water environments: Occurrence, persistence and concentration methods - A scoping review. Water Research 179:115899.

Ledford H (2020) Coronavirus breakthrough: dexamethasone is first drug shown to save lives. Nature 582(7813):469. doi: 10.1038/d41586-020-01824-5. 
Lenzen M, Li M, Malik A, Pomponi F, Sun YY, Wiedmann T, Faturay F, Fry J, Gallego B, Geschke A, Gómez-Paredes J, Kanemoto K, Kenway S, Nansai K, Prokopenko M, Wakiyama T, Wang Y, Yousefzadeh M (2020) Global socio-economic losses and environmental gains from the Coronavirus pandemic. PLoS One 15(7):e0235654.

Leroy EM, Ar Gouilh M, Brugère-Picoux J (2020) The risk of SARS-CoV-2 transmission to pets and other wild and domestic animals strongly mandates a one-health strategy to control the COVID-19 pandemic. One Health 100133.

Li C, Wang L, Ren L (2020c) Antiviral mechanisms of candidate chemical medicines and traditional Chinese medicines for SARSCoV-2 infection. Virus Research 286:198073.

Li F (2016) Structure, Function, and Evolution of Coronavirus Spike Proteins. Annual Reviews of Virology 3:237-261.

Li L, Qin L, Xu Z, Yin Y, Wang X, Kong B, Bai J, Lu Y, Fang Z, Song Q, Cao K, Liu D, Wang G, Xu Q, Fang X, Zhang S, Xia J, Xia J (2020a) Artificial intelligence distinguishes COVID-19 from community acquired pneumonia on chest CT. Radiology 200905.

Li Li, Shijin Gong, Jing Yan (2020b) Clinical observation and management of COVID-19 patients. Journal of Emerging Microbes \& Infections 9(1):687-690.

Li SY, Chen C, Zhang HQ, Guo HY, Wang H, Wang L, Zhang X, Hua SN, Yu J, Xiao PG, Li RS, Tan X. (2005) Identification of natural compounds with antiviral activities against SARS-associated coronavirus. Antiviral Research 67(1):18-23. doi: 10.1016/j.antiviral.2005.02.007.

Li Y, Liu X, Guo L, Li J, Zhong D, Zhang Y, Clarke M, Jin R (2020d) Traditional Chinese herbal medicine for treating novel coronavirus (COVID-19) pneumonia: protocol for a systematic review and meta-analysis. Systematic Reviews 9:75.

Lin C, Braund WE, Auerbach J, Chou JH, Teng JH, Tu P, Mullen J (2020) Policy Decisions and Use of Information Technology to Fight COVID-19, Taiwan. Emerging Infectious Diseases 26(7):1506-1512. doi: 10.3201/eid2607.200574.

Liu W, Tao ZW, Wang L, Yuan ML, Liu K, Zhou L, Wei S, Deng Y, Liu J, Liu HG, Yang M, Hu Y. (2020b) Analysis of factors associated with disease outcomes in hospitalized patients with 2019 novel coronavirus disease. Chinese Medical Journal 133(9): 10321038. doi: 10.1097/CM9.0000000000000775.

Liu Y, Mao B, Liang S, Yang JW, Lu HW, Chai YH, Wang L, Zhang L, Li QH, Zhao L, He Y, Gu XL, Ji XB, Li L, Jie ZJ, Li Q, Li XY, Lu HZ, Zhang WH, Song YL, Qu JM, Xu JF (2020c) Shanghai
Clinical Treatment Experts Group for COVID-19. Association between age and clinical characteristics and outcomes of COVID-19. European Respiratory Journal 55(5):2001112. doi: 10.1183/13993003.01112-2020.

Liu YC, Kuo RL, Shih SR (2020a) COVID-19: The first recommended coronavirus pandemic in history. Biomedical Journal 43(2):99-194 doi: 10.1016/j.bj.2020.04.007

Lodder W, de Roda Husman AM (2020) SARS-CoV-2 in wastewater: potential health risk, but also data source. Lancet Gastroenterology and Hepatology 5(6):533-534. doi: $10.1016 /$ S2468-1253(20)30087-X.

Lu H (2020b) Drug treatment options for the 2019-new coronavirus (2019-nCoV). BioScience Trends 14(1):69-71.

Lu QB, Jiang WL, Zhang X, Li HJ, Zhang XA, Zeng HL, Du J, Yang GL, Zhang LK, Li R, Fang LQ, Li H, Liu W (2020b) Comorbidities for fatal outcome among the COVID-19 patients: a hospital-based case-control study. Journal of Infection S01634453(20)30507-7. doi: 10.1016/j.jinf.2020.07.026.

Lu R, Wu X, Wan Z, Li Y, Zuo L, Qin J, Jin X, Zhang C (2020c) Development of a novel reverse transcription Loop-Mediated Isothermal Amplification method for rapid detection of SARS-CoV2. Virologica Sinica 35(3): 344-347. doi: 10.1007/s12250-02000218-1.

Lu R, Zhao X, Li J, Niu P, Yang B, Wu H, Wang W, Song H, Huang B, Zhu N, Bi Y, Ma X, Zhan F, Wang L, Hu T, Zhou H, Hu Z, Zhou W, Zhao L, Chen J, Meng Y, Wang J, Lin Y, Yuan J, Xie Z, Ma J, Liu WJ, Wang D, Xu W, Holmes EC, Gao GF, Wu G, Chen W, Shi W, Tan W. (2020a) Genomic characterisation and epidemiology of 2019 novel coronavirus: implications for virus origins and receptor binding. Lancet 395(10224):565-574. doi: 10.1016/S01406736(20)30251-8.

Lu YQ (2020a) A woman with fever and cough: coronavirus disease 2019. Internal and Emergency Medicine 1-2. doi:10.1007/s11739020-02321-3

Lübke N, Senff T, Scherger S, Hauka S, Andrée M, Adams O, Timm J, Walker A (2020) Extraction-free SARS-CoV-2 detection by rapid RT-qPCR universal for all primary respiratory materials. Journal of Clinical Virology 130:104579. doi: 10.1016/j.jcv.2020.104579.

Ma Y, Wu L, Shaw N, Gao Y, Wang J, Sun Y, Lou Z, Yan L, Zhang R, Rao Z (2015) Structural basis and functional analysis of the SARS coronavirus nsp14-nsp10 complex. Proceedings of the National Academy of Sciences USA 112:9436-9441.

Mahima, Verma AK, Tiwari R, Karthik K, Chakraborty S, Deb R, Dhama K (2013) Nutraceuticals from fruits and vegetables at a glance: a review. Journal of Biological Sciences 13(2): 38-47. 
Malik YS, Kumar N, Sircar S, Kaushik R, Bhat S, Dhama K, Gupta P, Goyal K, Singh MP, Ghoshal U, El Zowalaty ME, O R V, Yatoo MI, Tiwari R, Pathak M, Patel SK, Sah R, Rodriguez-Morales AJ, Ganesh B, Kumar P, Singh RK (2020b) Coronavirus Disease Pandemic (COVID-19): Challenges and a Global Perspective. Pathogens 9(7):E519.

Malik YS, Sircar S, Bhat S, Sharun K, Dhama K, Dadar M, Tiwari R, Chaicumpa W (2020a) Emerging novel coronavirus (2019$\mathrm{nCoV}$ )-current scenario, evolutionary perspective based on genome analysis and recent developments. Veterinary Quarterly 40(1):68-76.

Mallapaty S (2020) Coronavirus can infect cats - dogs, not so much. Nature doi: 10.1038/d41586-020-00984.

Mallik R, Dilip S, Rajib B (2020b) GPS tracking app for police to track ambulances carrying COVID-19 patients for ensuring safe distancing. Transactions of the Indian National Academy of Engineering 1-5. https ://doi.org/10.1007/s4140 3-020-00116 -8.

Mallik R, Hazarika AP, Ghosh Dastidar S, Sing D, Bandyopadhyay R (2020a) Development of an android application for viewing covid19 containment zones and monitoring violators who are trespassing into it using firebase and geofencing. Transactions of the Indian National Academy of Engineering 1-17. https ://doi.org/10.1007/s4140 3-020-00137 -3.

Mani JS, Johnson JB, Steel JC, Broszczak DA, Neilsen PM, Walsh KB, Naiker M (2020) Natural product-derived phytochemicals as potential agents against coronaviruses: a review. Virus Research 15;284:197989. doi: 10.1016/j.virusres.2020.197989.

Manson JE, Bassuk SS (2020) Commentary. Eliminating Vitamin D Deficiency During the COVID-19 Pandemic: A Call to Action. Metabolism S0026-0495(20): 30186-4

Market M, Angka L, Martel AB, Bastin D, Olanubi O, Tennakoon G, Boucher DM, Ng J, Ardolino M, Auer RC (2020) Flattening the COVID-19 Curve With Natural Killer Cell Based Immunotherapies. Frontiers in Immunology 11:1512. doi: 10.3389/fimmu.2020.01512.

Masters PS (2006) The molecular biology of coronaviruses. Advances in Virus Research 66:193-292.

Mawson AR (2013) Role of Fat-Soluble Vitamins A and D in the Pathogenesis of Influenza: A New Perspective. ISRN Infectious Diseases 2013:246737

McNamara T, Richt JA, Glickman L (2020) A Critical Needs Assessment for Research in Companion Animals and Livestock Following the Pandemic of COVID-19 in Humans. Vector Borne Zoonotic Diseases 20(6):393-405.

Meo SA, Klonoff DC, Akram J (2020) Efficacy of chloroquine and hydroxychloroquine in the treatment of COVID-19. European Review for Medical and Pharmacological Sciences 24(8):4539-4547.
Messina G, Polito R, Monda V, Cipolloni L, Di Nunno N, Di Mizio G, Murabito P, Carotenuto M, Messina A, Pisanelli D, Valenzano A, Cibelli G, Scarinci A, Monda M, Sessa F (2020) Functional Role of Dietary Intervention to Improve the Outcome of COVID-19: A Hypothesis of Work. International Journal of Molecular Sciences 21(9):3104. doi: 10.3390/ijms21093104.

Montalvan V, Lee J, Bueso T, De Toledo J, Rivas K (2020) Neurological manifestations of COVID-19 and other coronavirus infections: A systematic review. Clinical Neurology and Neurosurgery 194:105921.

Morais AHA, Passos TS, Maciel BLL, da Silva-Maia JK (2020) Can Probiotics and Diet Promote Beneficial Immune Modulation and Purine Control in Coronavirus Infection? Nutrients 12(6):E1737. doi: 10.3390/nu12061737.

Morawska L, Cao J (2020) Airborne transmission of SARS-CoV-2: The world should face the reality. Environment International 139:105730.

Mozaffarian D, Rosenberg I, Uauy R (2018) History of modern nutrition science -implications for current research, dietary guidelines, and food policy. BMJ 361:k2392.

Munjal A, Khandia R, Dhama K, Sachan S, Karthik K, Tiwari R, Malik YS, Kumar D, Singh RK, Iqbal HMN, Joshi SK (2017) Advances in Developing Therapies to Combat Zika Virus: Current Knowledge and Future Perspectives. Frontiers in Microbiology 8: 1469.

Murdoch DR, French NP (2020) COVID-19: another infectious disease emerging at animal-human interface. New Zealand Medical Journal 133(1510): 12-15.

Murugan D, Bhatia H, Sai VVR, Satija J (2020) P-FAB: a fiber-optic biosensor device for rapid detection of COVID-19. Transactions of the Indian National Academy of Engineering https ://doi.org/10.1007/s4140 3-020-00122 -w.

Myers EM (2020) Compounding Health Risks and Increased Vulnerability to SARS-CoV-2 for Racial and Ethnic Minorities and Low Socioeconomic Status Individuals in the United States. Preprints 2020, 2020040234 (doi: 10.20944/preprints202004.0234.v1).

Nag P, Sadani K, Mukherji S (2020) Optical fiber sensors for rapid screening of COVID-19. Transactions of the Indian National Academy of Engineering Eng. https ://doi.org/10.1007/s4140 3-020$00128-4$

Nal B, Chan C, Kien F, Siu L, Tse J, Chu K et al., (2005) Differential maturation and subcellular localization of severe acute 
respiratory syndrome coronavirus surface proteins $\mathrm{S}, \mathrm{M}$ and E. Journal of General Virology 86:1423-1434

Nasab MG, Saghazadeh A, Rezaei N (2020) SARS-CoV-2-A tough opponent for the immune system. Archives of Medical Research 2020 May 30. doi.org/10.1016/j.arcmed.2020.05.020

Nicola M, Alsafi Z, Sohrabi C, Kerwan A, Al-Jabir A, Iosifidis C, Agha M, Agha R (2020) The socio-economic implications of the coronavirus pandemic (COVID-19): A review. International Journal of Surgery 78: 185-193.

Nieto-Torres JL, Dediego ML, Alvarez E, Jiménez-Guardeño JM, Regla-Nava JA, Llorente M, Kremer L, Shuo S, Enjuanes L (2011) Subcellular location and topology of severe acute respiratory syndrome coronavirus envelope protein. Virology 415(2):69-82. doi: 10.1016/j.virol.2011.03.029.

Nikolich-Zugich J, Knox KS, Rios CT, Natt B, Bhattacharya D, Fain MJ (2020) SARS-CoV-2 and COVID-19 in older adults: what we may expect regarding pathogenesis, immune responses, and outcomes. Geroscience 42(2):505-514.

Omolo CA, Soni N, Fasiku VO, Mackraj I, Govender T (2020) Update on therapeutic approaches and emerging therapies for SARSCoV-2 virus. European Journal of Pharmacology 883:173348. doi: 10.1016/j.ejphar.2020.173348.

Oreshkova N, Molenaar RJ, Vreman S, Harders F, Oude Munnink BB, Hakze-van der Honing RW, Gerhards N, Tolsma P, Bouwstra R, Sikkema RS, Tacken MG, de Rooij MM, Weesendorp E, Engelsma MY, Bruschke CJ, Smit LA, Koopmans M, van der Poel WH, Stegeman A (2020) SARS-CoV-2 infection in farmed minks, the Netherlands, April and May 2020. Euro surveillance : bulletin Europeen sur les maladies transmissibles. European communicable disease bulletin 25 25(23):2001005. doi: 10.2807/15607917.ES.2020.25.23.2001005.

Orive G, Lertxundi U, Barcelo D (2020) Early SARS-CoV-2 outbreak detection by sewage-based epidemiology. Science of the Total Environment 732:139298.

Ou X, Liu Y, Lei X, Li P, Mi D, Ren L, Guo L, Guo R, Chen T, Hu J, Xiang Z, Mu Z, Chen X, Chen J, Hu K, Jin Q, Wang J, Qian Z (2020) Characterization of spike glycoprotein of SARS-CoV-2 on virus entry and its immune cross-reactivity with SARS-CoV. Nature Commununication 11(1):1620. doi: 10.1038/s41467-020-15562-9.

Panati K, Narala VR (2020) COVID-19 outbreak: an update on therapeutic options. SN Comprehensive Clinical Medicine 2:379-380.

Panyod S, Ho CT, Sheen LY (2020) Dietary therapy and herbal medicine for COVID-19 prevention: A review and perspective.
Journal of Traditional and Complementary Medicine 10(4):420-427. doi: 10.1016/j.jtcme.2020.05.004.

Patel SK, Saikumar G, Rana J, Dhama J, Yatoo MI, Tiwari R, Rodríguez-Morales AJ, Dhama K (2020b) Dexamethasone: A boon for critically ill COVID-19 patients? Travel Medicine and Infectious Disease 101844. doi: 10.1016/j.tmaid.2020.101844..

Patel SK, Singh R, Rana J, Tiwari R, Natesan S, Harapan H, Arteaga-Livias K, Bonilla-Aldana DK, Rodríguez-Morales AJ, Dhama K (2020a) The kidney and COVID-19 patients - important considerations. Travel Medicine and Infectious Disease 101831. doi: 10.1016/j.tmaid.2020.101831.

Prasad A, Muthamilarasan M, Prasad M (2020) Synergistic antiviral effects against SARS-CoV-2 by plant-based molecules. Plant Cell Reports 19:1-6.

Prasad M, Lambe UP, Brar B, Shah I, Manimegalai J, Ranjan K, Rao R, Kumar S, Mahant S, Khurana SK, Iqbal HMN, Dhama, K, Misri J, Prasad G (2018) Nanotherapeutics: An insight into healthcare and multi-dimensional applications in medical sector of the modern world. Biomedine and Pharmacotherapy 97: 1521-1537.

Premraj A, Aleyas AG, Nautiyal B, Rasool TJ (2020) Nucleic Acid and Immunological Diagnostics for SARS-CoV-2: Processes, Platforms and Pitfalls. Diagnostics (Basel) 10(11):E866. doi: 10.3390/diagnostics10110866.

Prompetchara E, Ketloy C, Palaga T (2020) Immune responses in COVID-19 and potential vaccines: Lessons learned from SARS and MERS epidemic. Asian Pacific Journal of Allergy and Immunology 38(1):1-9. doi: 10.12932/AP-200220-0772.

Qiu P, Zhou Y, Wang F, Wang H, Zhang M, Pan X, Zhao Q, Liu J (2020) Clinical characteristics, laboratory outcome characteristics, comorbidities, and complications of related COVID-19 deceased: a systematic review and meta-analysis. Aging Clinical and Experimental Research 1-10. doi: 10.1007/s40520-020-01664-3.

Quilliam RS, Weidmann M, Moresco V, Purshouse H, O'Hara Z, Oliver DM (2020) COVID-19: The environmental implications of shedding SARS-CoV-2 in human faeces. Environment International 140:105790.

Rahal A, Mahima, Verma AK, Kumar A, Tiwari R, Kapoor S, Chakraborty S, Dhama K (2014) Phytonutrients and nutraceuticals in vegetables and their multi-dimensional medicinal and health benefits for humans and their companion animals: A review. Journal of Biological Sciences 14(1): 1-19.

Rastogi S, Pandey DN, Singh RH (2020) COVID-19 Pandemic: A pragmatic plan for Ayurveda Intervention. Journal of Ayurveda and Integrative Medicine https://doi.org/10.1016/j.jaim.2020.04.002. 
Read SA, Obeid S, Ahlenstiel C, Ahlenstiel G (2019) The Role of Zinc in Antiviral Immunity. Advances in Nutrition 10(4):696-710. doi: 10.1093/advances/nmz013.

Riva L, Yuan S, Yin X, Martin-Sancho L, Matsunaga N, Pache L, Burgstaller-Muehlbacher S, De Jesus PD, Teriete P, Hull MV, Chang MW, Chan JF, Cao J, Poon VK, Herbert KM, Cheng K, Nguyen TH, Rubanov A, Pu Y, Nguyen C, Choi A, Rathnasinghe R, Schotsaert M, Miorin L, Dejosez M, Zwaka TP, Sit KY, MartinezSobrido L, Liu WC, White KM, Chapman ME, Lendy EK, Glynne RJ, Albrecht R, Ruppin E, Mesecar AD, Johnson JR, Benner C, Sun R, Schultz PG, Su AI, García-Sastre A, Chatterjee AK, Yuen KY, Chanda SK (2020) Discovery of SARS-CoV-2 antiviral drugs through large-scale compound repurposing. Nature 2020 Jul 24. doi: 10.1038/s41586-020-2577-1.

Rodriguez-Morales AJ, Bonilla-Aldana DK, Balbin-Ramon GJ, Rabaan AA, Sah R, Paniz-Mondolfi A, Pagliano P, Esposito S (2020a) History is repeating itself: Probable zoonotic spillover as the cause of the 2019 novel Coronavirus Epidemic. Le Infezioni in Medicina 28(1):3-5.

Rodriguez-Morales AJ., Bonilla-Aldana DK, Tiwari R, Sah R, Rabaan AA, Dhama K (2020b) COVID-19, an Emerging Coronavirus Infection: Current Scenario and Recent Developments - An Overview. Journal of Pure and Applied Microbiology 14(1): 05-12.

Romano L, Bilotta F, Dauri M, Macheda S, Pujia A, De Santis GL, Tarsitano MG, Merra G, Di Renzo L, Esposito E, De Lorenzo A (2020) Short Report - Medical nutrition therapy for critically ill patients with COVID-19. European Review for Medical and Pharmacological Science 24(7):4035-4039. doi: 10.26355/eurrev_202004_20874.

Ronco C, Reis T (2020) Kidney involvement in COVID-19 and rationale for extracorporeal therapies. Nature Reviews Nephrology 16(6):308-310. doi: 10.1038/s41581-020-0284-7.

Rosales-Mendoza S, Márquez-Escobar VA, González-Ortega O, Nieto-Gómez R, Arévalo-Villalobos JI (2020) What Does PlantBased Vaccine Technology Offer to the Fight against COVID19?. Vaccines (Basel) 8(2):E183.

Ruch TR, Machamer CE (2012a) A single polar residue and distinct membrane topologies impact the function of the infectious bronchitis coronavirus E protein. PLoS Pathogens 8: e1002674.

Ruch TR, Machamer CE (2012b) The coronavirus E protein: assembly and beyond. Viruses 4(3):363-82. doi: 10.3390/v4030363.

Sahraei Z, Shabani M, Shokouhi S, Saffaei A (2020) Aminoquinolines against coronavirus disease 2019 (COVID-19): chloroquine or hydroxychloroquine. International Journal of Antimicrobial Agents 55(4):105945. doi:10.1016/j.jjantimicag.2020.105945
Sakai Y, Kawachi K, Terada Y, Omori H, Matsuura Y, Kamitani W (2017) Two-amino acids change in the nsp4 of SARS coronavirus abolishes viral replication. Virology 510:165-174.

Salata C, Calistri A, Parolin C, Palù G (2020) Coronaviruses: a paradigm of new emerging zoonotic diseases. Pathogens and Disease 77(9):ftaa006.

Santos J, Brierley S, Gandhi MJ, Cohen MA, Moschella PC, Declan ABL (2020) Repurposing Therapeutics for Potential Treatment of SARS-CoV-2: A Review. Viruses 12(7):705. doi: 10.3390/v12070705.

Schloss J, Lauche R, Harnett J, Hannan N, Brown D, Greenfield T, Steel A (2020) Efficacy and safety of vitamin C in the management of acute respiratory infection and disease: A rapid review. Advances in Integrative Medicine. doi: 10.1016/j.aimed.2020.07.008.

Seo G, Lee G, Kim MJ, Baek SH, Choi M, Ku KB, Lee CS, Jun S, Park D, Kim HG, Kim SJ, Lee JO, Kim BT, Park EC, Kim SI (2020) Rapid detection of COVID-19 causative virus (SARS-CoV-2) in human nasopharyngeal swab specimens using field-effect transistorbased biosensor. American Chemical Society Nano 14:5135-5142. doi: 10.1021/acsnano.0c02823.

Setti L, Passarini F, De Gennaro G, Barbieri P, Perrone MG, Borelli M, Palmisani J, Di Gilio A, Piscitelli P, Miani A (2020) Airborne Transmission Route of COVID-19: Why 2 Meters/6 Feet of InterPersonal Distance Could Not Be Enough. International Journal of Environmental Research and Public Health 17(8):E2932.

Shanmugaraj B, Siriwattananon K, Wangkanont K, Phoolcharoen W (2020) Perspectives on monoclonal antibody therapy as potential therapeutic intervention for Coronavirus disease-19 (COVID-19). Asian Pacific Journal of Allergy and Immunology 1: 108.https://doi.org/10.12932/AP-200220-0773

Sharun K, Tiwari R, Iqbal Yatoo M, Patel SK, Natesan S, Dhama J, Malik YS, Harapan H, Singh RK, Dhama K. (2020b) Antibodybased immunotherapeutics and use of convalescent plasma to counter COVID-19: advances and prospects. Expert Opinion on Biological Therapy 20(9):1033-1046. doi: 10.1080/14712598.2020.1796963.

Sharun K, Tiwari R, Patel SK, Karthik K, Iqbal Yatoo M, Malik YS, Singh KP, Panwar PK, Harapan H, Singh RK, Dhama K (2020a) Coronavirus disease 2019 (COVID-19) in domestic animals and wildlife: advances and prospects in the development of animal models for vaccine and therapeutic research. Human Vaccines and Immunotherapeutics 16(12): doi: 10.1080/21645515.2020.1807802.

Sheahan TP, Sims AC, Zhou S, Graham RL, Pruijssers AJ, Agostini ML, Leist SR, Schäfer A, Dinnon KH 3rd, Stevens LJ, Chappell JD, 
Lu X, Hughes TM, George AS, Hill CS, Montgomery SA, Brown AJ, Bluemling GR, Natchus MG, Saindane M, Kolykhalov AA, Painter G, Harcourt J, Tamin A, Thornburg NJ, Swanstrom R, Denison MR, Baric RS (2020) An orally bioavailable broadspectrum antiviral inhibits SARS-CoV-2 in human airway epithelial cell cultures and multiple coronaviruses in mice. Science Translational Medicine 12(541):eabb5883. doi: 10.1126/scitranslmed.abb5883.

Shen K, Yang Y, Wang T, Zhao D, Jiang Y, Jin R, Zheng Y, Xu B, Xie Z, Lin L, Shang Y, Lu X, Shu S, Bai Y, Deng J, Lu M, Ye L, Wang X, Wang Y, Gao L (2020) China National Clinical Research Center for Respiratory Diseases; National Center for Children's Health, Beijing, China; Group of Respirology, Chinese Pediatric Society, Chinese Medical Association; Chinese Medical Doctor Association Committee on Respirology Pediatrics; China Medicine Education Association Committee on Pediatrics; Chinese Research Hospital Association Committee on Pediatrics; Chinese Nongovernment Medical Institutions Association Committee on Pediatrics; China Association of Traditional Chinese Medicine, Committee on Children's Health and Medicine Research; China News of Drug Information Association, Committee on Children's Safety Medication; Global Pediatric Pulmonology Alliance. Diagnosis, treatment, and prevention of 2019 novel coronavirus infection in children: experts' consensus statement. World Journal of Pediatrics 16(3):223-231. doi: 10.1007/s12519-020-00343-7.

Shi J, Wen Z, Zhong G, Yang H, Wang C, Huang B, Liu R, He X, Shuai L, Sun Z, Zhao Y, Liu P, Liang L, Cui P, Wang J, Zhang X, Guan Y, Tan W, Wu G, Chen H, Bu Z (2020a) Susceptibility of ferrets, cats, dogs, and other domesticated animals to SARScoronavirus 2. Science 8:eabb7015.

Shi Y, Wang Y, Shao C, Huang J, Gan J, Huang X, Bucci E, Piacentini M, Ippolito G, Melino G (2020b) COVID-19 infection: the perspectives on immune responses. Cell Death and Differentiation 27(5):1451-1454. doi: 10.1038/s41418-020-0530-3.

Singh RK, Dhama K, Chakraborty S, Tiwari R, Natesan S, Khandia R, Munjal A, Vora KS, Latheef SK, Karthik K, Singh Malik Y, Singh R, Chaicumpa W, Mourya DT (2019) Nipah virus: epidemiology, pathology, immunobiology and advances in diagnosis, vaccine designing and control strategies - a comprehensive review. Veterinary Quarterly 39(1): 26-55.

Sinha SK, Prasad SK, Islam MA, Gurav SS, Patil RB, AlFaris NA, Aldayel TS, AlKehayez NM, Wabaidur SM, Shakya A (2020) Identification of bioactive compounds from Glycyrrhiza glabra as possible inhibitor of SARS-CoV-2 spike glycoprotein and nonstructural protein-15: a pharmacoinformatics study. Journal of Biomolecular Structure \& Dynamics 1-15. doi: 10.1080/07391102.2020.1779132.
Sit THC, Brackman CJ, Ip SM, Tam KWS, Law PYT, To EMW, Yu VYT, Sims LD, Tsang DNC, Chu DKW, Perera RAPM, Poon LLM, Peiris M (2020) Infection of dogs with SARS-CoV-2. Nature doi: 10.1038/s41586-020-2334-5.

South AM, Tomlinson L, Edmonston D, Hiremath S, Sparks MA (2020) Controversies of rennin-angiotensin system inhibition during the COVID-19 pandemic. Nature Reviews Nephrology 16(6):305-307.

Stebbing J, Phelan A, Griffin I, Tucker C, Oechsle O, Smith D, Richardson P (2020) COVID-19: combining antiviral and antiinflammatory treatments. Lancet Infectious Disease 20(4):400-402. doi: 10.1016/S1473-3099(20)30132-8.

Su S, Wong G, Shi W, Liu J, Lai ACK, Zhou J, Liu W, Bi Y, Gao GF (2016) Epidemiology, Genetic Recombination, and Pathogenesis of Coronaviruses. Trends Microbiol 24(6):490-502. doi: 10.1016/j.tim.2016.03.003.

Subissi L, Posthuma CC, Collet A, Zevenhoven-Dobbe JC, Gorbalenya AE, Decroly E, Snijder EJ, Canard B, Imbert I (2014) One severe acute respiratory syndrome coronavirus protein complex integrates processive RNA polymerase and exonuclease activities. Proceedings of the National Academy of Sciences USA 111:E3900E3909.

Swamy MK, Akhtar MS, Sinniah UR (2016) Antimicrobial Properties of Plant Essential Oils against Human Pathogens and Their Mode of Action: An Updated Review. Evidence Based Complementary and Alternatative Medicine 2016:3012462. doi: $10.1155 / 2016 / 3012462$.

Tan BK, Vanitha J (2004) Immunomodulatory and antimicrobial effects of some traditional chinese medicinal herbs: a review. Current Medicinal Chemistry 11(11):1423-30. doi: 10.2174/0929867043365161.

Tang X, Wu C, Li X, Song Y, Yao X, Wu X, Duan Y, Zhang H, Wang Y, Qian Z, Cui J, Lu J (2020a) On the origin and continuing evolution of SARS-CoV-2. National Science Review 7(6):10121023. https://doi.org/10.1093/nsr/nwaa036

Tang YW, Schmitz JE, Persing DH, Stratton CW (2020b) The laboratory diagnosis of COVID-19 infection: Current issues and challenges. Journal of Clinical Microbiology 58(6):e00512-20. doi: 10.1128/JCM.00512-20. pii: JCM.00512-20.

Thibault R, Seguin P, Tamion F, Pichard C, Singer P (2020) Nutrition of the COVID-19 patient in the intensive care unit (ICU): a practical guidance. Critical Care 24:447.

Tiwari R, Dhama K, Sharun K, Iqbal Yatoo M, Malik YS, Singh R, Michalak I, Sah R, Bonilla-Aldana DK, Rodriguez-Morales AJ 
(2020) COVID-19: animals, veterinary and zoonotic links. Vashist SK (2020) In Vitro Diagnostic Assays for COVID-19: Veterinary Quarterly 40(1):169-182. doi: Recent Advances and Emerging Trends. Diagnostics (Basel) 10.1080/01652176.2020.1766725. 10(4):E202.

Tiwari R, Latheef SK, Ahmed I, Iqbal H, Bule MH, Dhama K, Samad HA, Karthik K, Alagawany M, El-Hack ME, Yatoo MI, Farag MR (2018) Herbal Immunomodulators - A Remedial Panacea for Designing and Developing Effective Drugs and Medicines: Current Scenario and Future Prospects. Current Drug Metabolism 19(3): 264-301.

Tiwari S, Verma PC, Singh PK, Tuli R (2009) Plants as bioreactors for the production of vaccine antigens. Biotechnology Advances 27(4):449-67.

Tobaiqy M, Qashqary M, Al-Dahery S, Mujallad A, Hershan AA, Kamal MA, Helmi N (2020) Therapeutic management of patients with COVID-19: a systematic review. Infection Prevention in Practice 2(3):100061.

Tomar S, Johnston ML, St. John SE, Osswald HL, Nyalapatla PR, Paul LN, Ghosh AK, Denison MR, Mesecar AD (2015) Ligandinduced dimerization of middle east respiratory syndrome (MERS) coronavirus nsp5 protease (3CL ${ }^{\mathrm{pro}}$ ) implications For nsp5 Regulation And The Development Of Antivirals. Journal of Biological Chemistry 290:19403-19422.

Tripathi S, Agrawal A (2020) Blood plasma microfluidic device: aiming for the detection of COVID-19 antibodies using an on chip ELISA platform. Transactions of the Indian National Academy of Engineering 1-4. https://doi.org/10.1007/s41403-020-00123-9.

Tripathy S, Singh SG (2020) Label-free electrochemical detection of DNA hybridization: a method for COVID-19 diagnosis. Transactions of the Indian National Academy of Engineering https ://doi.org/10.1007/s4140 3-020-00103-Z.

Uddin M, Mustafa F, Rizvi TA, Loney T, Suwaidi HA, Al-Marzouqi AH, Eldin AK, Alsabeeha N, Adrian TE, Stefanini C, Nowotny N (2020) SARS-CoV-2/COVID-19: Viral genomics, epidemiology, vaccines, and therapeutic interventions. Viruses 12(5):526.

Udugama B, Kadhiresan P, Kozlowski HN, Malekjahani A, Osborne M, Li VYC, Chen H, Mubareka S, Gubbay JB, Chan WCW (2020) Diagnosing COVID-19: The Disease and Tools for Detection. ACS Nano 14(4):3822-3835.

van Doremalen N, Bushmaker T, Morris DH, Holbrook MG, Gamble A, Williamson BN, Tamin A, Harcourt JL, Thornburg NJ, Gerber SI, Lloyd-Smith JO, de Wit E, Munster VJ (2020) Aerosol and Surface Stability of SARS-CoV-2 as Compared with SARSCoV-1. New England Journal of Medicine 382(16):1564-1567. doi: 10.1056/NEJMc2004973.
Vellingiri B, Jayaramayya K, Iyer M, Narayanasamy A, Govindasamy V, Giridharan B, Ganesan S, Venugopal A, Venkatesan D, Ganesan H, Rajagopalan K, Rahman PKSM, Cho SG, Kumar NS, Subramaniam MD (2020) COVID-19: A promising cure for the global panic. Science of the Total Environment 725:138277.

Walls AC, Park YJ, Tortorici MA, Wall A, McGuire AT, Veesler D (2020) Structure, Function, and Antigenicity of the SARS-CoV-2 Spike Glycoprotein. Cell 181(2):281-292.e6.

Wang J, Zhu L, Liu L, Zhao XA, Zhang Z, Xue L, Yan X, Huang S, Li Y, Cheng J, Zhang B, Xu T, Li C, Ji F, Ming F, Zhao Y, Shao H, Sang D, Zhao H, Guan X, Chen X, Chen Y, Issa R, Wei J, Huang R, Zhu C, Wu C. (2020a) Overweight and obesity are risks factors of severe illness in patients with COVID-19. Obesity (Silver Spring). doi: 10.1002/oby.22979.

Wang M, Cao R, Zhang L, Yang X, Liu J, Xu M, Shi Z, Hu Z, Zhong W, Xiao G (2020b) Remdesivir and chloroquine effectively inhibit the recently emerged novel coronavirus (2019-nCoV) in vitro. Cell Research 30(3):269-271.

Waqas Khan HM, Parikh N, Megala SM, Predeteanu GS (2020) Unusual Early Recovery of a Critical COVID-19 Patient After Administration of Intravenous Vitamin C. The American journal of Case Reports 21:e925521. doi: 10.12659/AJCR.925521.

Weng JK (2020) Plant Solutions for the COVID-19 Pandemic and Beyond: Historical Reflections and Future Perspectives. Molecular Plant 13:803-807.

Wu C, Chen X, Cai Y, Xia J, Zhou X, Xu S, Huang H, Zhang L, Zhou X, Du C, Zhang Y, Song J, Wang S, Chao Y, Yang Z, Xu J, Zhou X, Chen D, Xiong W, Xu L, Zhou F, Jiang J, Bai C, Zheng J, Song Y (2020a) Risk Factors Associated With Acute Respiratory Distress Syndrome and Death in Patients With Coronavirus Disease 2019 Pneumonia in Wuhan, China. JAMA Internal Medicine 180(7):1-11. doi: 10.1001/jamainternmed.2020.0994.

Wu D, Lewis ED, Pae M, Meydani SN (2019) Nutritional Modulation of Immune Function: Analysis of Evidence, Mechanisms, and Clinical Relevance. Frontiers in Immunology 9:3160.

Wu R, Wang L, Kuo HD, Shannar A, Peter R, Chou PJ, Li S, Hudlikar R, Liu X, Liu Z, Poiani GJ, Amorosa L, Brunetti L, Kong AN (2020c) An Update on Current Therapeutic Drugs Treating COVID-19. Current Pharmacology Reports:1-15. doi: 10.1007/s40495-020-00216-7. 
Wu SY, Yau HS, Yu MY, Tsang HF, Chan LWC, Cho WCS, Yu CS, Yim A, Li M, Wong YKE, Pei XM, Wong CSC. (2020b) The Diagnostic Methods in the COVID-19 Pandemic, Today and in the Future. Expert Review of Molecular Diagnostics doi: 10.1080/14737159.2020.1816171.

Xu Y, Baylink DJ, Chen CS, Reeves ME, Xiao J, Lacy C, Lau E, Cao H (2020) The importance of vitamin D metabolism as a potential prophylactic, immunoregulatory and neuroprotective treatment for COVID-19. Journal of Translational Medicine 18(1):322. doi: 10.1186/s12967-020-02488-5.

Yamin M (2020) Counting the cost of COVID-19. International Journal of Information Technology 1-7. doi: 10.1007/s41870-02000466-0.

Yang J, Zheng Y, Gou X, Pu K, Chen Z, Guo Q, Ji R, Wang H, Wang Y, Zhou Y (2020a) Prevalence of comorbidities and its effects in patients infected with SARS-CoV-2: a systematic review and meta-analysis. International Journal of Infectious Diseases 94:91-95. doi: 10.1016/j.ijid.2020.03.017.

Yang P, Wang X (2020) COVID-19: a new challenge for human beings. Cellular and Molecular Immunology 17(5):555-557. doi:10.1038/s41423-020-0407-x

Yang T, Wang YC, Shen CF, Cheng CM (2020b) Point-of-Care RNA-Based Diagnostic Device for COVID-19. Diagnostics (Basel) 10(3): 165 .

Yang Y, Islam MS, Wang J, Li Y, Chen X (2020c) Traditional Chinese Medicine in the Treatment of Patients Infected with 2019. New Coronavirus (SARS-CoV-2): A Review and Perspective. International Journal of Biological Sciences 16(10):1708-1717.

Yao TT, Qian JD, Zhu WY, Wang Y, Wang GQ (2020) A systematic review of lopinavir therapy for SARS coronavirus and MERS coronavirus-A possible reference for coronavirus disease-19 treatment option. Journal of Medical Virology 92(6):556-63.

Yatoo MI, Hamid Z, Parray OR, Wani AH, Ul Haq A, Saxena A, Patel SK, Pathak M, Tiwari R, Malik YS, Sah R, Rabaan AA, Rodriguez Morales AJ, Dhama K (2020) COVID-19 - Recent advancements in identifying novel vaccine candidates and current status of upcoming SARS-CoV-2 vaccines. Human Vaccines and Immunotherapeutics 1-14. doi: 10.1080/21645515.2020.1788310.

Ye Y, Hogue BG (2007) Role of the coronavirus E viroporin protein transmembrane domain in virus assembly. Journal of Virology 81: 3597-3607.

Yoshimoto FK (2020) The proteins of severe acute respiratory syndrome coronavirus-2 (SARS CoV-2 or n-COV19), the cause of COVID-19. Protein Journal 39: 198-216. https://doi.org/10.1007/s10930-020-09901-4
Yu L, Wu S, Hao X, Dong X, Mao L, Pelechano V, Chen WH, Yin X (2020) Rapid Detection of COVID-19 Coronavirus Using a Reverse Transcriptional Loop-Mediated Isothermal Amplification (RT-LAMP) Diagnostic Platform. Clinical Chemistry 66(7):975-977. doi: 10.1093/clinchem/hvaa102.

Yuen KS, Ye ZW, Fung SY, Chan CP, Jin DY (2020) SARS-CoV-2 and COVID-19: The most important research questions. Cell \& Bioscience 10:40.

Zha L, Li S, Pan L, Tefsen B, Li Y, French N, Chen L, Yang G, Villanueva EV (2020) Corticosteroid treatment of patients with coronavirus disease 2019 (COVID-19). The Medicinal Journal of Australia 212(9):416-420. doi: 10.5694/mja2.50577.

Zhai P, Ding Y, Wu X, Long J, Zhong Y, Yiming Li (2020) The epidemiology, diagnosis and treatment of COVID-19. International Journal of Antimicrobial Agents 55(5):105955. doi: 10.1016/j.jjantimicag.2020.105955.

Zhang C, Wu Z, Li JW, Zhao H, Wang GQ (2020f) The cytokine release syndrome (CRS) of severe COVID-19 and Interleukin-6 receptor (IL-6R) antagonist Tocilizumab may be the key to reduce the mortality. International Journal of Antimicrobial Agents. 2020:105954. 10.1016/j.ijantimicag.2020.105954.

Zhang H, Penninger JM, Li Y, Zhong N, Slutsky AS (2020e) Angiotensin-converting enzyme 2 (ACE2) as a SARS-CoV-2 receptor: molecular mechanisms and potential therapeutic target. Intensive Care Medicine 2020e; 46(4):586-590. doi:10.1007/s00134-020-05985-9

Zhang L, Yu J, Zhou Y, Shen M, Sun L (2020g) Becoming a Faithful Defender: Traditional Chinese Medicine against Coronavirus Disease 2019 (COVID-19). American Journa of Chinese Medicine 48(4):763777. doi:10.1142/S0192415X2050038X

Zhang L, Jackson CB, Mou H, Ojha A, Rangarajan ES, Izard T, Farzan M, Choe H (2020a) The D614G mutation in the SARS-CoV2 spike protein reduces $\mathrm{S} 1$ shedding and increases infectivity. bioRxiv2020 Jun 12;Doi: 10.1101/2020.06.12.148726. Preprint.

Zhang N, Wang L, Deng X, Liang R, Su M, He C, Hu L, Su Y, Ren J, Yu F, Du L, Jiang S (2020c) Recent advances in the detection of respiratory virus infection in humans. Journal of Medical Virology 92(4):408-417.

Zhang R, Li Y, Zhang AL, Wang Y, Molina MJ (2020b). Identifying airborne transmission as the dominant route for the spread of COVID-19. Procedings of the National Academy of Sciences USA 117(26):14857-14863.

Zhang Y, Xu Q, Sun Z, Zhou L (2020d) Current targeted therapeutics against COVID-19: Based on first-line experience in 
China. Pharmacological Research 157:104854. doi: 10.1016/j.phrs.2020.104854.

Zhao S, Ge X, Wang X, Liu A, Guo X, Zhou L, Yu K, Yang H (2015) The DEAD-box RNA helicase 5 positively regulates the replication of porcine reproductiv e and respiratory syndrome virus by interacting with viral Nsp9 in vitro. Virus Research 195:217-224.

Zheng Z, Peng F, Xu B, Zhao J, Liu H, Peng J, Li Q, Jiang C, Zhou Y, Liu S, Ye C, Zhang P, Xing Y, Guo H, Tang W (2020) Risk factors of critical \& mortal COVID-19 cases: A systematic literature review and meta-analysis. Journal of Infections 81(2):e16-e25. doi: 10.1016/j.jinf.2020.04.021.

Zhong H, Wang Y, Zhang ZL, Liu YX, Le KJ, Cui M, Yu YT, Gu ZC, Gao Y, Lin HW (2020a). Efficacy and safety of current therapeutic options for COVID-19 - lessons to be learnt from SARS and MERS epidemic: A systematic review and meta-analysis. Pharmacological Research 157:104872. 10.1016/j.phrs.2020.104872.
Zhong J, Tang J, Ye C, Dong L (2020b) The immunology of COVID-19: is immune modulation an option for treatment?. The Lancet Rheumatology 2(7): E428-E436. https://doi.org/10.1016/S2665-9913(20)30120-X

Zhou M, Zhang X, Qu J (2020a) Coronavirus disease 2019 (COVID-19): a clinical update. Frontiers of Medicine 14(2):126135.

Zhou P, Yang XL, Wang XG, Hu B, Zhang L, Zhang W, Si HR, Zhu Y, Li B, Huang CL, Chen HD (2020b) A pneumonia outbreak associated with a new coronavirus of probable bat origin. Nature 579(7798):270-3.

Zhu N, Zhang D, Wang W, Li X, Yang B, Song J, Zhao X, Huang B, Shi W, Lu R, Niu P, Zhan F, Ma X, Wang D, Xu W, Wu G, Gao GF, Tan W (2020) China Novel Coronavirus Investigating and Research Team. A Novel Coronavirus from Patients with Pneumonia in China, 2019. New England Journal of Medicine 382(8):727-733. doi: 10.1056/NEJMoa2001017. 